\title{
El sistema de mérito en el empleo público: principales singularidades y analogías respecto del empleo en el sector privado *
}

SUMARIO: I. INTRODUCCIÓN. II. IDENTIFICACIÓN DE LAS PRINCIPALES SINGULARIDADES DEL SISTEMA DE FUNCIÓN PÚBLICA EN ESPAÑA. 1. La cobertura de puestos en las Administraciones Públicas frente a la libertad de contratación empresarial. 1.1. Consideración preliminar: la configuración jurídica del derecho fundamental de acceso en igualdad de condiciones a las funciones y cargos públicos. 1.2. Las especifidades en los procesos de selección y de provisión de puestos en las Administraciones Públicas. A) La detección de necesidades y su formalización en la Oferta de Empleo Público: las previsiones anuales. B) La separación entre los órganos de selección y los órganos competentes para el nombramiento. C) La predeterminación del sistema de selección. D) La controversia en torno a la utilización de técnicas de evaluación diferentes a las tradicionales pruebas de conocimientos. 2. Singularidades derivadas del ejercicio de las potestades de organización por las diferentes Administraciones Públicas. 2.1. Los supuestos de movilidad forzosa. 2.1.1. Movilidad funcional con carácter definitivo. 2.1.2. Movilidad funcional con carácter provisional. 2.1.3. Movilidad geográfica. 2.2. Modificación de las condiciones de trabajo. 2.2.1. Cambios en el contenido de las funciones. A) Cambios definitivos. B) Cambios provisionales. 2.2.2. Cambios en las condiciones en el ejercicio de las funciones. III. ALGUNAS REFLEXIONES SOBRE LA NECESARIA RENOVACIÓN DEL ACTUAL SISTEMA DE EMPLEO PÚBLICO. 1. El reto de no repetir errores históricos. 2. La revisión de algunos conceptos e instituciones básicos. A) La reformulación del contenido sustantivo de las ideas de mérito y capacidad. B) Principio de mérito y carrera administrativa. C) Derecho al cargo, inamovilidad y situaciones administrativas. D) Sobre la necesaria reconducción del estéril debate entre funcionarios y laborales como una discusión sobre regimenes jurídicos. IV. BIBLIOGRAFIA.

\section{INTRODUCCIÓN}

El objetivo del presente artículo es realizar un análisis de nuestro vigente sistema de mérito abordándolo desde una doble perspectiva:

* El presente artículo ha sido finalizado cuando aún está pendiente de tramitarse legalmente la aprobación del denominado Pacto laboral entre empresarios y sindicatos; $y$, asimismo, en estos momentos circula un borrador de anteproyecto de Estatuto de la Función Pública, que no sabemos si llegará a buen puerto. 
por un lado, la óptica del Derecho, que nos ayudará a explicar el porqué de las singularidades del sistema en comparación con el empleo privado; y, por otro lado, el enfoque de la gestión, que nos obliga a interrogarnos sobre el cómo hacer funcionar el sistema de recursos humanos en el específico marco de las múltiples y heterogéneas organizaciones que integran nuestras Administraciones Públicas. Conviene remarcar que ambas perspectivas son complementarias (PraTs: 1993), y que su armonización es imprescindible para fundamentar cualquier propuesta de reforma del sistema de mérito que no quiera reproducir errores históricos, como, por ejemplo, el desvincular la reforma de la función pública de la correlativa reforma organizativa (NIETO: 1989), $o$, más recientemente, incorporar instrumentos y técnicas de gestión cuya complejidad o inadecuación los invalida y desacredita en el sector público (PARADA: 1996).

Nuestro análisis se divide en dos grandes partes. En una primera parte se identifican las principales singularidades del sistema de mérito en el empleo público, y para ello nos adentramos en el estudio de la realidad actual, teniendo en cuenta la imprescindible perspectiva histórica, para interrogarnos sobre qué diferencias deben ser consideradas como auténticas singularidades y cuáles son meros privilegios o injustificadas limitaciones. Y en la segunda parte nos adentramos en el estudio de las causas que justifican la renovación o refundación del actual sistema de mérito, lo que podría concretarse en un futuro Estatuto de la Función Pública.

\section{IDENTIFICACIÓN DE LAS PRINCIPALES SINGULARIDADES DEL SISTEMA DE FUNCIÓN PUBLICA EN ESPAÑA}

La valoración de cada singularidad deberá hacerse con relación a los principios que explican la actuación y el funcionamiento de las Administraciones Públicas al servicio de los intereses generales (NIETO: 1991; GARCIA DE ENTERRIA: 1995, 110). Es evidente que hay principios comunes a las organizaciones con independencia de que sean públicas o privadas (como los de eficacia, eficiencia, jerarquía, etc.), pero no es menos cierto que la diferente finalidad de esas organizaciones modula el alcance e impacto de esos principios comunes (PAREJO: 1989). Además, la valoración de las singularidades de nuestro sistema de función pública se enmarca en unos principios específicos como son la objetividad, la imparcialidad, la igualdad, el mérito o la capacidad (MORELL: 1994).

La comparación del sistema de función pública con el empleo privado nos muestra que las dos grandes diferencias tradicionales se encuentran precisamente en los momentos de inicio y de extinción de 
la relación. Frente a la libertad de contratación y la legalización del despido objetivo en la empresa, la Administración se encuentra sujeta, por un lado, a respetar el derecho fundamental de acceso en igualdad de condiciones a funciones y cargos públicos según los principios de mérito y capacidad y, por otro lado, debe respetar la inamovilidad relacional como garantía de la imparcialidad de los funcionarios. Pero en los últimos tiempos está generándose un importante debate común tanto del sector público como del sector privado: la reforma del modelo de gestión de personal basada en el fortalecimiento de las potestades de organización o de dirección, lo cual se concreta en una nueva regulación de los supuestos de movilidad forzosa y de la ampliación de las potestades de modificación de las funciones y de las condiciones de su ejercicio. Nos interesa analizar el impacto de este proceso en el sector público, en la medida en que supone un resquebrajamiento del principio tradicional de inamovilidad de los funcionarios y abre la puerta a la normalización de sistemas de provisión hasta ahora considerados como excepcionales (la redistribución, la reasignación de efectivos, la nueva regulación de la comisión de servicios forzosa, etc.).

Por último, remarcar que el presente es un análisis parcial de las singularidades de la función pública, pues no se abordan temas como la responsabilidad civil, penal o disciplinaria o el sistema retributivo, temas a los que colateralmente se refieren otros autores en este mismo número de la revista.

\section{La cobertura de puestos en las Administraciones Públicas FRENTE A LA LIBERTAD DE CONTRATACIÓN EMPRESARIAL}

En este apartado trataremos las especificidades del vigente marco juridico en los procesos de cobertura de vacantes y dejamos para la parte final de este estudio nuestras consideraciones sobre el manifiesto divorcio entre ese marco y la realidad cotidiana, donde nos planteamos la conveniencia de debatir una reforma en profundidad del vigente sistema de mérito.

\subsection{Consideración preliminar: la configuración jurídica del derecho fundamental de acceso en igualdad de condiciones a las funciones y cargos públicos}

La principal innovación de la Constitución de 1978 al reconocer la igualdad en el acceso a las funciones y cargos públicos es el otorgarle naturaleza jurídica de derecho fundamental. El Tribunal Constitucional ha establecido la siguiente doctrina en cuanto a la calificación jurídica y contenido del derecho de acceso en condiciones de igualdad: 
a) Se trata de un derecho fundamental de carácter puramente reaccional y de configuración legal. La primera consecuencia es que no estamos ante un derecho fundamental sustantivo, pues en el art. 23.2 CE se limita a garantizar una situación jurídica de igualdad para los ciudadanos en el acceso a los cargos y funciones públicas, con la consecuencia de que no pueden establecerse requisitos para acceder a los mismos que tengan carácter discriminatorio. Entre los autores es José María BAÑo LEÓN quien, siguiendo a la doctrina alemana, ha sido el primero en utilizar la categoría de derecho público subjetivo "de protección modal" (modal adwehrechte), que conlleva el deber de los poderes públicos de actuar de un determinado modo (en nuestro caso la omisión de todo trato discriminatorio o, en otras palabras, cuando hay una abstención de tratar de manera diferente lo que es igual) y el derecho del ciudadano a reaccionar mediante los correspondientes recursos procesales contra la infracción de ese deber. La segunda consecuencia es que los requisitos para el acceso se pueden establecer mediante leyes $\mathrm{o}$, también, por medio de normas reglamentarias cuando exista una previa remisión legislativa que lo autorice. Y la tercera consecuencia es que la infracción de este derecho fundamental no se puede reducir procesalmente a una cuestión de personal cuya resolución finaliza en el correspondiente Tribunal Superior de Justicia, sino que cabe su defensa ante el Tribunal Supremo y ante el Tribunal Constitucional.

b) La determinación del contenido sustantivo del art. 23.2 se puede realizar desde una doble perspectiva. Así, desde una óptica negativa, en la misma línea de la concepción francesa y de la tradición española, del art. 23.2 no nace derecho alguno a la ocupación o al desempeño de funciones determinadas, y ni siquiera el derecho a proponerse como aspirante a ellos. $\mathrm{Y}$, desde una perspectiva positiva, el art. 23.2 CE reconoce el derecho a todas aquellas personas que reúnan los requisitos previamente establecidos a acceder, permanecer y ejercer el correspondiente empleo público. Por acceso debe entenderse tanto el ingreso por primera vez como la ocupación sucesiva de diferentes puestos una vez incorporados al empleo público, lo cual incluye los diferentes supuestos de provisión de puestos y de promoción. La permanencia en el puesto conlleva el derecho a no ser removido sino por las causas y con las garantías legalmente establecidas, pero no puede exigirse, en el caso de los funcionarios, que la situación estatutaria quede congelada en los términos en que se hallaba regulada al tiempo de su ingreso. Por último, respecto del derecho al pleno ejercicio o desempeño de la función o cargo público el Tribunal Constitucional entiende que conlleva una serie de facultades que no pueden ser menoscabadas o desconocidas mediante perturbaciones ilegítimas en su desempeño, pues las mismas forman parte del status propio de cada cargo o función.

c) La formulación de los requisitos y de las reglas de procedimiento para el acceso al empleo público deben reunir las notas de generalidad, abstracción y objetividad. La exigencia de generalidad y abstracción 
tiene como consecuencia la prohibición de referencias individualizadas o de pretericiones ad personam, en la terminología del Tribunal Constitucional; y esta doble exigencia derivada del art. 23.2 CE es también vinculante para el legislador, al que le está vedada la utilización de una ley singular en ese sentido. Pero la posibilidad de la previa determinación de las personas que reúnen las condiciones establecidas en aplicación del principio constitucional de mérito no implica referencia individualizada y concreta, salvo que el mérito en cuestión carezca de fundamentación objetiva. Y la fundamentación de la objetividad del art. 23.2 CE la encuentra el Tribunal Constitucional en su necesaria vinculación con el art. 103.3 CE, lo que implica que los requisitos de acceso deben referirse exclusivamente a los criterios de mérito y capacidad, pues al margen de ellos se incurre en arbitrariedad. Además de su necesaria conexión con el mérito y la capacidad los requisitos exigibles deben reunir las características de razonabilidad y proporcionalidad; entendiendo por razonabilidad la exigencia de relación con la función o cargo a desempeñar, y refiriendo la proporcionalidad a la adecuada ponderación de cada requisito en relación con la valoración del conjunto de ellos.

El papel del mérito y la capacidad en la nueva configuración constitucional se concreta en una idea: son el parámetro de constitucionalidad del derecho fundamental del art. 23.2 CE. Un parámetro cuya eficacia se articula de forma diferente en relación con cada manifestación de los Poderes Públicos. Así, para el legislador son los principios juridicos que están incorporados al derecho fundamental de acceso en condiciones de igualdad. Para la Administración son los únicos criterios de selección utilizable y cuyo contenido debe concretar en cada caso, para cumplir con la doble finalidad de seleccionar a los más idóneos y garantizar la igualdad en el proceso de selección. Y para los Tribunales son conceptos jurídicos indeterminados, cuyo control es obligado para dilucidar si ha sido lesionado o sacrificado indebidamente un derecho fundamental.

El Tribunal Constitucional entiende que la Constitución concede un amplio margen de regulación o concreción del mérito y la capacidad tanto al legislador como a la Administración; y el mismo Tribunal establece como límite a esa libertad «la necesidad de no crear desigualdades que sean arbitrarias, en cuanto ajenas, no referidas o incompatibles con los principios de mérito y capacidad".

\subsection{Las especificidades en los procesos de selección y de provisión de puestos en las Administraciones Públicas}

La cobertura de vacantes en las Administraciones Públicas se aproxima a la libertad de contratación en las empresas a medida que se 
debilita la aplicación de los principios de mérito y capacidad como únicos criterios de decisión. Así, el nombramiento de personal eventual, que es aquél que ejerce funciones expresamente calificadas de confianza o asesoramiento especial, es un noinbramiento libre y el cese también lo es y se produce automáticamente cuando cesa la autoridad que le nombró (art. 20.2 LMRFP); estamos ante un caso en el que el único criterio es el de la confianza personal, con independencia del mérito. Un caso más restringido de libertad de nombramiento es cuando por cubrir una vacante se acude al procedimiento de la libre designación, aquí el círculo es más limitado (debe producirse entre funcionarios que reúnan determinados requisitos y siguiendo un procedimiento establecido - art. 20.1 LMRPF-) pero la confianza es el criterio predominante, sin que ningún candidato pueda alegar «mejor mérito" para impugnar la decisión. Y un tercer supuesto en el que se debilita parcialmente el principio de mérito es el de nombramiento de funcionarios interinos, que se produce por razones de urgencia (art. 27 RGIPP) y para cubrir transitoriamente puestos reservados a funcionarios de carrera: en estos casos se sigue un procedimiento de selección diferente al utilizado para escoger al funcionario de carrera titular (Orden de 28 de febrero de 1986).

Con estos ejemplos queremos poner de relieve que las especificidades que analizaremos a continuación se refieren en su totalidad a los supuestos de personal con vinculación permanente (los funcionarios de carrera y el personal laboral con contrato indefinido).

A) La detección de necesidades y su formalización en la Oferta de Empleo Público: las previsiones anuales

El sector público debe objetivar sus previsiones de necesidades de personal externo con carácter anual y a través de un instrumento que se creó en el año 1984 con voluntad de instaurar una lógica de planificación de los recursos humanos: la Oferta de Empleo Público (art. 18 LMRFP), que en la práctica se ha desvirtuado considerablemente por su incorrecta utilización y se cuestiona su alcance a la vista de la nueva figura de los Planes de Empleo, que nacieron con carácter de excepcionalidad en una coyuntura de crisis económica y ahora pretende generalizarse su utilización como requisito previo para la mayoría de decisiones de gestión de personal en la Administración del Estado (art. 2 RGIPP). El nuevo Reglamento General de Ingreso del personal al servicio de la Administración General del Estado y de Provisión de puestos de trabajo y de Promoción profesional de los funcionarios de la Administración General del Estado, aprobado por el Real Decreto 364/1995 (RGIPP), ha introducido dos elementos de 
flexibilidad en la nueva regulación de la Oferta de Empleo Público (OEP): primero, con carácter excepcional, cuando existan necesidades urgentes de incorporación de personal, se podrán aprobar ofertas de empleo público para ámbitos administrativos específicos (art. 8.2 RGIPP), lo cual supone admitir ofertas de empleo parciales; y, segundo, se elimina la obligatoriedad de proceder a convocar los procesos selectivos dentro del primer trimestre natural y a que los mismos finalicen antes del primero de octubre. Pero ya anteriormente la OEP había sufrido otros cambios importantes; así, desde el año 1990 (Ley 4/1990) se suprime la obligatoriedad de ofertar todos los puestos vacantes, se podrá limitar a los que se considere convenientes en función de la política de personal y presupuestaria de cada momento, y desde el año 1994 (Ley 22/1993) se suprime la posibilidad de cubrir hasta un diez por ciento adicional a lo previsto en la OEP; por último, desde el año 1995 (Ley 41/1994) se establece que el número de plazas de nuevo ingreso será inferior al que resulte de la tasa de reposición de efectivos (en cumplimiento del Acuerdo AdministraciónSindicatos para el período 1995-1997).

Antes de procederse a aprobar la OEP por el Gobierno (a propuesta del Ministerio para las Administraciones Públicas, previa negociación con los sindicatos y con informe favorable del Ministerio de Economía y Hacienda) se ha debido proceder a intentar cubrir las vacantes con los recursos internos, lo que supone que se han debido realizar las correspondientes convocatorias de concursos y a la vista del resultado de éstas se determina el número exacto de vacantes y se decide cuáles se dotan presupuestariamente para ese ejercicio. Pero, hoy por hoy, este paso previo es más teórico que real, cuando resulta clave para una verdadera política de personal que, entre otras cosas, se tengan en cuenta las expectativas de unos funcionarios que tienen reconocido un genérico derecho a la carrera y a la promoción.

En el sector privado todo este proceso estaría en la lógica de maximizar el rendimiento y expectativas de su personal y planificar las nuevas incorporaciones.

En conclusión, la verdadera singularidad en esta materia se encuentra en la obligatoriedad de la publicación en un plazo concreto y su no posibilidad de revocación arbitraria. La aprobación y publicación de la OEP en los Boletines Oficiales es un primer paso que vincula al propio Gobierno y que abre las expectativas de los ciudadanos para ejercer su derecho a participar en condiciones de igualdad en una competición fomalmente justa, en la que existe un trato especial para las personas que sufran una discapacidad mínima del treinta y dos por ciento, pues a ellas se les debe reservar un tres por ciento de las vacantes (en el ámbito estatal), reserva que, por otro lado, también, se contempla en el sector privado. 
B) La separación entre los órganos de selección y los órganos competentes para el nombramiento

Esta separación es una de las principales garantías en cuanto a la objetividad del proceso de selección y se completa con el principio de imparcialidad que debe presidir la composición y actuación de los órganos de selección (BEATO ESPEJO: 1992, 1673). Esta doble garantia es esencial para la credibilidad del proceso, que hoy en día se ve cuestionado frecuentemente a la vista de la composición del órgano de selección, en el que el principio de especialización se ha visto reducido en la práctica al cumplimiento de la exigencia legal de poseer un nivel de titulación igual o superior al exigido para el ingreso en el cuerpo o escala correspondiente (art. 19.2 LMRFP) (ALEGRE ÁviLA: 1993, 895). Recordemos que hasta el año 1990 en la Administración del Estado era frecuente que formaran parte de los Tribunales de selección altos cargos, pues ni la LMRFP ni el Reglamento General de Ingreso del año 1984 lo excluían, y tan sólo desde el año 1995 es una exclusión permanente, pues el nuevo RGIPP exige la condición de funcionario de carrera para formar parte (art. 11). Pero esa "politización" es todavía más flagrante en el ámbito local, donde el Alcalde o Presidente de la Corporación es el presidente nato de todos los Tribunales (art. 4.f Real Decreto 896/1991), con lo que en la práctica puede acabar infringiéndose ese principio de separación, pues normalmente le corresponde al Alcalde realizar los nombramientos (MARTíN-RETORTILLO, L.: 1993). También hay que remarcar que la despolitización de los órganos de selección no implica que la única vía sea la funcionarización de sus componentes, sino la de fomentar la especialización, sean o no funcionarios.

Hace ya años que la doctrina, al poco de aprobarse la reforma de 1984 , remarcaba que uno de los problemas a resolver era precisamente la composición y funcionamiento de los órganos de selección (SANTAMARIA PASTOR: 1986). Por ello, es necesario poner fin a la desvirtuación permanente del principio de especialización, reduciéndolo a una mera exigencia de titulación equivalente al candidato a seleccionar, pues en realidad se hace referencia al dominio específico de la materia objeto de las pruebas y de las diferentes técnicas de selección. El Reglamento de 1984 exigía que la mitad más uno de los miembros poseyera una titulación correspondiente al área de conocimiento de la convocatoria (cosa que el RGIPP no exige) y ello debe complementarse con el profesionalismo del seleccionador, pues no basta con los conocimientos cuando hay que decidir entre varios candidatos y es necesario el dominio de técnicas de selección en las que hay que estar formado y entrenado. Reivindicar el fin del "amateurismo" es apostar por la credibilidad del sistema, tanto en el aspecto técnico como en el de la 
imparcialidad. Los procesos de selección exigen unas determinadas habilidades técnicas y una dedicación necesaria, poco conciliable con los apremiantes quehaceres cotidianos. Por ello, convendría también replantearse la actual configuración de los órganos permanentes de selección, concebidos sobre todo por razones cuantitativas y no cualitativas (art. 12 RGIPP), y dar el salto hacia un nuevo modelo organizativo que deje de concebir los procesos selectivos como unas prácticas mecánicas y engorrosas que se reiteran año tras año, reproduciendo errores y deficiencias y desvinculándose del resultado del proceso.

Un tema siempre pendiente es el de una regulación específica del funcionamiento de los órganos de selección, pues no es suficiente con la remisión genérica a la normativa sobre órganos colegiados. Estamos hablando de un proceso en el que está en juego un derecho fundamental (art. 23.2 CE) y en el que la decisión de fondo es prácticamente inatacable en base al criterio de discrecionalidad técnica, por lo que adquieren especial relieve los aspectos formales que garanticen la transparencia de las decisiones mediante una adecuada documentación del proceso y una fundamentación objetiva de las decisiones.

Por último, la regulación vigente se plantea la composición de los órganos de selección desde la perspectiva de garantizar la imparcialidad de las decisiones mediante las siguientes previsiones: a) no puede haber mayoría de los miembros del Cuerpo o Escala que se evalúa, salvo las excepciones legalmente previstas (especialmente en el campo docente e investigador); b) no pueden formar parte aquellos que puedan tener interés en algún candidato por haberse dedicado a la preparación de aspirantes en los últimos cinco años; c) no pueden formar parte altos cargos (salvo en la Administración local y en algunas Comunidades Autónomas); d) pueden incorporarse asesores especialistas para todas o algunas de las pruebas, y actúan con voz y sin voto para ayudar al Tribunal en su decisión; y e) no puede formar parte cualquier persona que esté inmersa en alguna de las causas legales de abstención o recusación. Un tema controvertido respecto de su composición imparcial es si en los órganos de selección puede estar un representante de los funcionarios; por ejemplo, el actual RGIPP lo admite cuando se trata de seleccionar personal laboral (art. 30) o cuando se trata de proveer puestos de funcionarios mediante concurso de méritos (art. 46.1). Creemos que en la fase de selección no está justificada la diferenciación en función de que se trate de escoger a funcionarios o a personal laboral (CASTILLO BLANCO: 1993, 113 y 114), pues las reglas de imparcialidad deben aplicarse en el mismo sentido, pero aquí es posible que nos encontremos con una reminiscencia del Reglamento General de Ingreso del año 1984, en el que el personal laboral normalmente se seleccionaba por concurso y el personal funcionario por oposición, y para contrarrestar las suspicacias de 
parcialidad que siempre han levantado los concursos en la Administración se decidió ofrecer una imagen de transparencia admitiendo que los representantes sindicales estuvieran en los órganos de selección; pero ahora que el nuevo RGIPP ha suprimido esa distinción no vemos el fundamento del trato desigualatorio salvo que se pretenda establecer como regla que siempre que la selección sea mediante concurso (algo realmente excepcional) se debe garantizar la presencia de representantes de los funcionarios. También llama la atención de que no se regule actualmente la composición de los Tribunales para seleccionar personal laboral, más allá de indicar que serán número impar (art. 30 RGIPP), cuando ese personal representa alrededor del cuarenta por ciento del total de empleados públicos.

En el sector privado la separación entre órgano seleccionador y órgano decisor, que no está vinculado por la propuesta, acostumbra a realizarse también por razones cuantitativas (número de candidatos) o cualitativas (complejidad del proceso), pero el empresario es libre de decidir el procedimiento o de pactarlo en el correspondiente convenio. Por tanto, sí podemos considerar esta diferenciación como una verdadera singularidad del sector público.

\section{C) La predeterminación del sistema de selección}

La LMRFP no predetermina cuál debe ser el sistema de selección a utilizar, se limita a enumerar los tres clásicos (oposición, concurso y concurso-oposición) y se exigen dos requisitos: que se garanticen los principios constitucionales de igualdad, inérito, capacidad y publicidad y que se cuide especialmente la conexión entre el tipo de pruebas a superar y la adecuación a los puestos de trabajo que se hayan de desempeñar (art. 19.1). Es por norma reglamentaria, primero el Reglamento General de Ingreso del año 1984 y luego en 1995 el nuevo RGIPP, donde se establece el criterio de utilización. En ambos Reglamentos se recoge la tradición histórica de la oposición como sistema ordinario de selección, «salvo cuando, por la naturaleza de las funciones a desempeñar, sea más adecuada la utilización del concurso-oposición y, excepcionalmente, el de concurso" (art. 4 de ambos reglamentos). A la hora de interpretar qué se entiende por "la naturaleza de las funciones a desempeñar» en el Reglamento de 1984 teníamos una pista aparentemente clara: las funciones atribuidas al personal laboral justificaban la utilización del concurso como sistema normal, y si tenemos en cuenta que la redacción inicial de la LMRFP (art. 15) abría la puerta a que la regla general fuera el personal laboral, nos hubiéramos encontrado con que el concurso hubiera sustituido a la oposición como sistema ordinario de selección del personal al servicio de las 
Administraciones Públicas. Pero el Tribunal Constitucional invirtió esa regla con su ya conocida sentencia del año 1987, afirmando que la regla general debía ser el régimen funcionarial. No obstante, lo inconsistente de esta vinculación del sistema de selección con el régimen de personal quedaba en evidencia en el mismo Reglamento del año 1984, pues se decía que el sistema normal sería el concurso para seleccionar personal laboral salvo por la naturaleza de las tareas (al igual que en el caso de los funcionarios) o cuando por el número de aspirantes resulte más adecuado este sistema; y es este segundo criterio, el cuantitativo, el que desautoriza una diferenciación cualitativa en el uso de los sistemas vinculados al régimen jurídico del personal. Así lo ha entendido el RGIPP que ha roto esa vinculación entre concurso y personal laboral (art. 29).

Por tanto, actualmente nos encontramos con que la Administración debe utilizar ordinariamente la oposición y excepcionalmente el concurso, quedando el concurso-oposición para cuando se presente como la fórmula más adecuada para la naturaleza de las funciones, determinación ésta que, según la doctrina, poco o nada aporta porque ¿en el caso de qué funciones puede ser no adecuado valorar los méritos? (SANCHEZ MORON: 1996, 124.) La experiencia nos demuestra que el concurso-oposición normalmente se utiliza cuando hay un número importante de aspirantes que previamente tiene o ha tenido algún vínculo con la Administración.

La controversia jurisprudencial y normativa sobre la correcta utilización del concurso-oposición ha hecho aflorar un debate sobre las relaciones entre el mérito y la capacidad, dando por supuesto que existe un fundamento objetivo que permite diferenciar ambos términos cuya formulación normativa funde sus raíces en los albores del siglo XIX (sobre la fragilidad de esta imposición volveremos en la última parte de este estudio). Este debate gira en torno a los siguientes interrogantes: ¿Qué principio debe prevalecer en un proceso de selección: el mérito o la capacidad? y ¿qué proporción cuantitativa se le debe atribuir a cada uno en el resultado final determinante de la idoneidad del candidato? En este punto encontramos dos soluciones normativas contrapuestas, avaladas por dos correlativas interpretaciones jurisprudenciales.

Una solución normativa, inicialmente adoptada por el Estado y por determinadas Comunidades Autónomas, se fundamenta en que la capacidad y el mérito tienen el mismo valor y relevancia constitucional, de manera que los puntos obtenidos en aplicación de uno de estos principios (mérito) no valen menos que los conseguidos en virtud del otro (capacidad), ni hay base constitucional para sobreprimar o considerar unos como condición inexcusable de los otros. Esta es la postura defendida por el Tribunal Supremo en un caso ya clásico: la impugnación de unas convocatorias de la Junta de Extremadura en las que se utilizaba 
el sistema de concurso-oposición, y se posibilitaba que personas que suspendieron la fase de oposición acabaron obteniendo la plaza de funcionario al sumarles los puntos de la fase de concurso, y personas que habían obtenido una buena calificación en la fase de oposición se quedasen sin plaza por no llevar puntos en su "mochila" de la fase de concurso, por no haber prestado servicios previamente en la Administración. La consecuencia de esta postura es que personas que no han acreditado la capacidad mínima exigida (aprobar la fase de oposición) puedan convertirse en funcionarios por el mero cómputo del tiempo previamente desempeñado en un puesto, siendo irrelevante si ese desempeño ha sido correcto o incorrecto, pues no hay evaluación del mismo. La otra solución normativa prevista en alguna Comunidad Autónoma (Cataluña, por ejemplo), y con la que viene a coincidir la doctrina del Tribunal Constitucional que revocó la sentencia del Tribunal Supremo sobre el caso de la Junta de Extremadura (STC 67/1989, de 16 de abril), parte de la base de que la capacidad prevalece sobre el mérito, de tal manera que si no se demuestra el mínimo de capacidad exigido en la fase de oposición ya no se pueden tener en cuenta los méritos acreditados, y cuando corresponda valorarlos no podrán sobrepasar un determinado tanto por ciento de la puntuación total del conjunto del concurso-oposición (por ejemplo, en el caso de Cataluña, el máximo es una tercera parte, o el mismo Tribunal Constitucional ha admitido que los méritos puedan alcanzar una valoración del cuarenta y cinco por ciento).

Esta interpretación del Tribunal Constitucional, aunque responde a los interrogantes planteados afirmando la prevalencia del principio de capacidad sobre el de mérito y admitiendo una valoración mayor de la fase de oposición sobre la de concurso, sigue sin proporcionar el porqué de esa prevalencia al no establecer una relación directa con el criterio de idoneidad para el desempeño del puesto. Lo cual nos lleva a plantear que el verdadero debate debe girar en torno a qué es lo que se puede valorar o medir en todo proceso de selección y cómo realizar esa valoración.

Pues bien, toda esta problemática jurídica es irrelevante en el sector privado donde, más allá del principio de no discriminación, no existe predeterminación alguna en cuanto a los sistemas selectivos ni se plantea debate alguna sobre el contenido de las pruebas, salvo en la medida en que pueden afectar a derechos constitucionales fundamentales.

D) La controversia en torno a la utilización de técnicas de evaluación diferentes a las tradicionales pruebas de conocimientos

Desde el año 1984 se admite con carácter general la «realización de tests psicotécnicos, entrevistas y cualesquiera otros sistemas que 
aseguren la objetividad y racionalidad del proceso selectivo" (fórmula que repite el art. 82 del vigente RGIPP del año 1995). Pero esta clase de pruebas o de métodos de evaluación alternativos a las tradicionales pruebas memorísticas de conocimientos suscitan recelos y plantean problemas en las Administraciones públicas por dos razones: primera, no existen unas pautas mínimas de utilización, pues los reglamentos se limitan a exigir que sean objetivas y racionales, y segunda, su descrédito por su incorrecta utilización, especialmente en el caso de las entrevistas. Estos problemas han aflorado en los conflictos que ha generado su aplicación, como ponen de manifiesto algunas sentencias del Tribunal Supremo. Así, en el año 1993 (R. Ar. 3892), el Tribunal Supremo desestima un recurso de la Federación de Administración Pública de Comisiones Obreras en el que se impugnaba el Reglamento General de Provisión de Puestos del año 1990, porque establecía la posibilidad de realizar una entrevista para comprobar los méritos específicos adecuados a las características del puesto (art. 15-4), ya que entendían los recurrentes que "se introduce con ello un elemento de discrecionalidad técnica secreta, no controlable por el poder judicial... siendo la entrevista una especie de examen secreto". Ante esta descalificación tan contundente, que refleja una visión negativa en la que se valora la entrevista en función de sus «aplicaciones desviadas», el Tribunal Supremo defiende la legalidad de la entrevista y su compatibilidad con los principios de mérito y capacidad en los siguientes términos:

"Nuevamente hemos de distinguir ente la validez de la norma y la eventualidad de aplicaciones desviadas, a lo que parecen referirse más bien las alegaciones de la recurrente y que no pueden tenerse en consideración al enjuiciar la norma.

No estimamos que la entrevista desnaturalice el concurso, ni que sea contraria a su estructura, debiendo compartir sobre el particular la tesis del Abogado del Estado porque se trata tan sólo de un medio de comprobación de méritos alegados, y en el tal sentido sirve para hacer efectivos los principios de mérito $y$ capacidad.

Resulta excesivo cualificar la entrevista de examen secreto sin garantias, pues en ella, si se efectúa correctamente, cual debe presumirse, tan sólo se deben evaluar los méritos alegados por el concursante, lo que es base de objetividad suficiente.

El inevitable subjetivismo de la ponderación no es de signo cualitativamente distinto de cualquier otra ponderación del mérito, sin que pueda darse por sentado que el grado de subjetivismo debe ser superior en el mecanismo de control que constituye la entrevista, y aun en la bipótesis de que pudiera serlo, ello 
no sería elemento decisivo para su rechazo, pues no es aceptable que de por si tenga que ser vicioso.

La especial idoneidad de la entrevista para comprobar con ella que determinados méritos alegados corresponden en efecto al aspirante, $y$ no se simulan con simples apreciaciones documentales (piénsese, por ejemplo, en estudios y trabajos científicos que pueden aportarse como propios y cuya elaboración puede ser de terceros), compensaria el posible mayor grado de subjetivismo en la ponderación, si es que realmente lo bubiera.

Por lo demás, que entre entrevista y concurso de méritos, como medio aquélla para el control de éstos, no existe incompatibilidad conceptual, lo revela el becho de que en nuestra legislación de rango superior existen previsiones de esos mecanismos, como es de ver en la Ley Orgánica del Poder Judicial (Art. 313, párrafo 5).

Esta sentencia es bastante representativa de la problemática que encierra la entrevista como método de evaluación, y que como nos recuerda James G. GOODALE «la entrevista es probablemente el sistema de selección más profundamente investigado $y$, sin embargo, el peor aplicado de todos los instrumentos de selección» (1992). El desprestigio de la entrevista en el sector público y su concepción como "un examen secreto", tal y como la califican los recurrentes, se debe a errores en su aplicación como los siguientes:

- Realizar la entrevista sin que esté formalmente constituido el Tribunal Calificador, o decidir distribuirse entre cada uno de sus miembros la realización de las entrevistas por separado.

- Realizar la entrevista sin previamente haber acordado las preguntas y temas a plantear a todos los candidatos y los criterios de su valoración.

- No dejar constancia documental suficiente revisable por un Tribunal de Justicia, haciendo incontrolable cualquier arbitrariedad.

A modo de ejemplo, nos parece ilustrativa la sistematización que GoODAle hace de los fallos más comunes en las entrevistas de selección y de su propuesta de mejora, que es aplicable tanto al sector público como al privado y que se basa en estudios empíricos realizados en los Estados Unidos, donde las normas sobre seleccción son comunes a ambos sectores y son controlables por la Comisión de Igualdad de Oportunidades en el Empleo que, a su vez, ha elaborado unas normas muy detalladas sobre como deben desarrollarse los proceso de selección (son las denominados Guías Uniformes). Veamos estos dos cuadros comparativos: 


\section{FALLOS DE LA ENTREVISTA DE SELECCIÓN}

I. La mala planificación

a) Los entrevistadores no conocen sus objetivos

b) Los entrevistadores no planifican ni estructuran la entrevista

c) Los entrevistadores no conocen el puesto de trabajo al que aspira el candidato

II. El enfoque psiquiátrico

a) El entrevistador asume el rol de psiquiatra aficionado

b) El candidato es juzgado con criterios inapropiados

III. Los entrevistados son seres humanos

a) Abundan las actitudes personales y los estereotipos

b) Aparecen sesgos de primeras impresiones y se precipitan la conclusiones

c) Olvidos del entrevistador

IV. Las entrevistas violan las normas de la Comisión de Igualdad de Oportunidades en el Empleo

a) El entrevistador trata temas que están prohibidos

b) La evaluación se basa en informaciones irrelevantes

\section{MEJORA DE LA ENTREVISTA COMO INSTRUMENTO DE SELECCIÓN}

I. La planificación apropiada

a) Conocer los propios objetivos

b) Planificar un esquema de la entrevista para alcanzar esos objetivos

c) Conocer lo mejor posible el puesto de trabajo que ha de ser cubierto

II. La evaluación de la capacidad del candidato para el rendimiento

a) Evaluar a los candidatos en función de su capacidad para realizar tareas relacionadas con el puesto de trabajo

b) Evaluar los deseos del candidato de trabajar en la organización

III. La construcción de una entrevista mejor

a) Siempre que sea posible, adaptar la entrevista al puesto de trabajo específico

b) Tratar sistemáticamente en la entrevista temas relacionados con el puesto de trabajo

c) Registrar las evaluaciones y la documentación en que se apoyan

IV. El cumplimiento en las entrevistas de las normas de la Comisión de Igualdad de Oportunidades en el Empleo

a) Ajustar la entrevista al puesto de trabajo

b) Cubrir sistemáticamente los temas relacionados con el puesto de trabajo

c) Evaluar a los candidatos en términos relacionados con el puesto de trabajo

d) Guardar las evaluaciones y la documentación en que se apoyan.

En esta misma línea, cuando se aprobó el Reglamento de Provisión de Puestos del año 1990, el Ministerio para las Administraciones Públicas elaboró un «Manual de procedimiento del sistema de provisión de puestos de trabajo por concurso específico para la Administración Pública", 
consciente de las dificultades que entrañaba el nuevo modelo de provisión de puestos, que es el vigente actualmente (Arts. 44 y 45 RGIPP), y en el que dice que "la entrevista versará sobre los méritos específicos adecuados a las caracteristicas del puesto de acuerdo con lo expuesto en la convocatoria y, en su caso, sobre la memoria, pudiendo extenderse a la comprobación de los méritos alegados» (Art. 45.4 - la última frase no estaba en el Reglamento del año 1990). Pues bien, en el Manual se dan las siguientes pautas sobre la realización de la entrevista:

"Es la parte fundamental y decisoria del proceso de selección. La entrevista ha de estar previamente acordada, de forma que todos los matices, informaciones y aspectos relevantes queden adecuadamente cubiertos. Asimismo, habrá de garantizarse, con la plena objetividad, la percepción de los puntos fuertes y débiles de los candidatos.

La entrevista deberá ceñirse a dos aspectos básicos: de una parte, a lo que sea más importante respecto al bistorial profesional del candidato, de otra, a contestar y resolver preguntas relacionadas con situaciones y tomas de decisiones que pudieran darse en el ejercicio profesional del puesto.

Son dos, pues, los aspectos básicos sobre los que debe versar la entrevista: de un lado, la explotación de la experiencia profesional, $y$, de otro, la comprobación de las actitudes y capacidades psico-profesionales del candidato.

Las entrevistas han de ser realizadas de forma que no sean excesivamente largas, prolijas o que deriven hacia temas triviales o sin relación directa con el proceso de selección.

Los entrevistadores actuarán con la máxima profesionalidad, objetividad, discreción y tacto, procurando en todo momento que el entrevistado se sienta cómodo y relajado.

Bajo ninguna circunstancia puede intentarse invadir la intimidad del candidato, hacerle caer en errores o contradicciones, confundirle o dejarle en inferioridad de condiciones frente a otros candidatos».

El uso de las pruebas psicotécnicas plantea dos problemas: el de su elaboración y el de su valoración. Si tomamos como referencia el perfil tipo de lo que se quiere que sea un miembro del Cuerpo o Escala habremos de basarnos en las funciones genéricas previamente reglamentadas; pero si el referente son las "tareas propias de las plazas que se convocan" el perfil debe fundamentarse en el puesto concreto que se habrá de desempeñar.

En el segundo problema, la valoración de las pruebas psicotécnicas en el proceso de selección, acostumbra a producirse un oscurantismo difícilmente compatible con el principio de seguridad aplicado a la capacidad y al mérito. Por ejemplo, en las convocatorias suelen valorarse conjuntamente las pruebas psicotécnicas con las de conocimientos, pero 
sin concretar el peso específico de cada una; otras veces se utiliza en primer lugar y con carácter eliminatorio la prueba psicotécnica sin dar oportunidad a valorar los conocimientos. Ante la ausencia de una reglamentación general sobre el uso, y a la vista de los principios de mérito y capacidad, parece sensato garantizar que su elaboración debe fundarse en datos objetivos y estudios específicos que puedan ser objeto de revisión judicial cuando se cuestiona su adecuación en relación con los puestos de trabajo a cubrir, pues pueden producirse las mismas irregularidades o deficiencias que en cualquier prueba de conocimientos. El control judicial de los test psicotécnicos ha sido planteado como una exigencia constitucional por nuestro Tribunal Supremo en su Sentencia de 5 de octubre de 1989 (R. Ar. 6.848):

"El empleo de test psicológico de personalidad en el procedimiento de selección para el acceso a la función pública, y, en concreto, de los dirigidos a evaluar la dirección e intensidad de las aptitudes que, en contraposición con los instrumentos de medida de actitudes, no proporcionan un perfil de la capacidad intelectual del candidato sino de aspectos de personalidad en términos de tendencia a reaccionar hacia estimulos, plantea el importante problema de su adecuación a criterios objetivos que permitan el control de la decisión selectiva en la que han de verse garantizados los principios constitucionales de igualdad, mérito y capacidad, asi como el de publicidad, art. 103.3 de la Constitución y 19 de la Ley 30/1984, de Medidas para la Reforma de la Función Pública» (Fundamento de Derecho noveno).

Para garantizar la utilización "objetiva y racional" de los test psicotécnicos nos parece interesante la propuesta elaborada por un Grupo de Trabajo, (creado en el año 1992 entre el Instituto Nacional de Administración Pública, la Dirección General de la Función Pública del Ministerio para las Administraciones Públicas y la Federación Española de Municipios y Provincias) sobre los criterios a utilizar por las Administraciones Locales al aplicar el Real Decreto 896/1991, de 7 de junio, por el que se establecen las reglas y los programas mínimos a que debe ajustarse el procedimiento de selección de sus funcionarios. Entre las técnicas a utilizar incorpora la técnica del profesiograma, mediante el cual «se trata de determinar convencionalmente el perfil del funcionario a seleccionar; de tal manera que, tanto respecto de sus aptitudes como de sus conocimientos, se le atribuye un grado de exigencia que es mayor a medida que lo es el puesto atribuido". Nos parece suficientemente ilustrativo reflejar los profesiogramas correspondientes a tres categorías de funcionarios típicos de la Administración Local: el administrativo, el técnico de administración general y el policía local. 
PROFESIOGRAMA DE UN TÉCNICO ADMINISTRACIÓN GENERAL

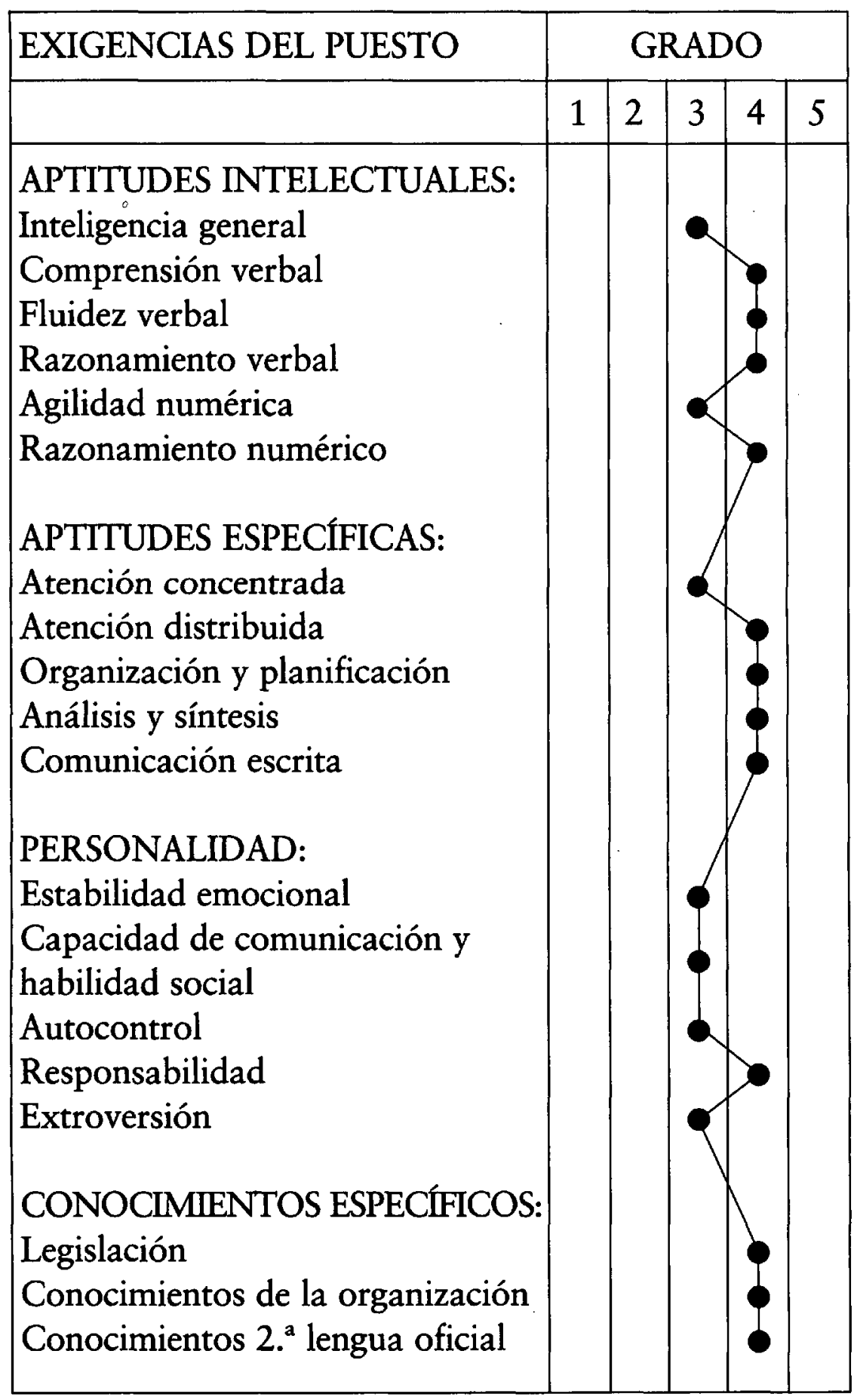


PROFESIOGRAMA DE UN POLICÍA LOCAL

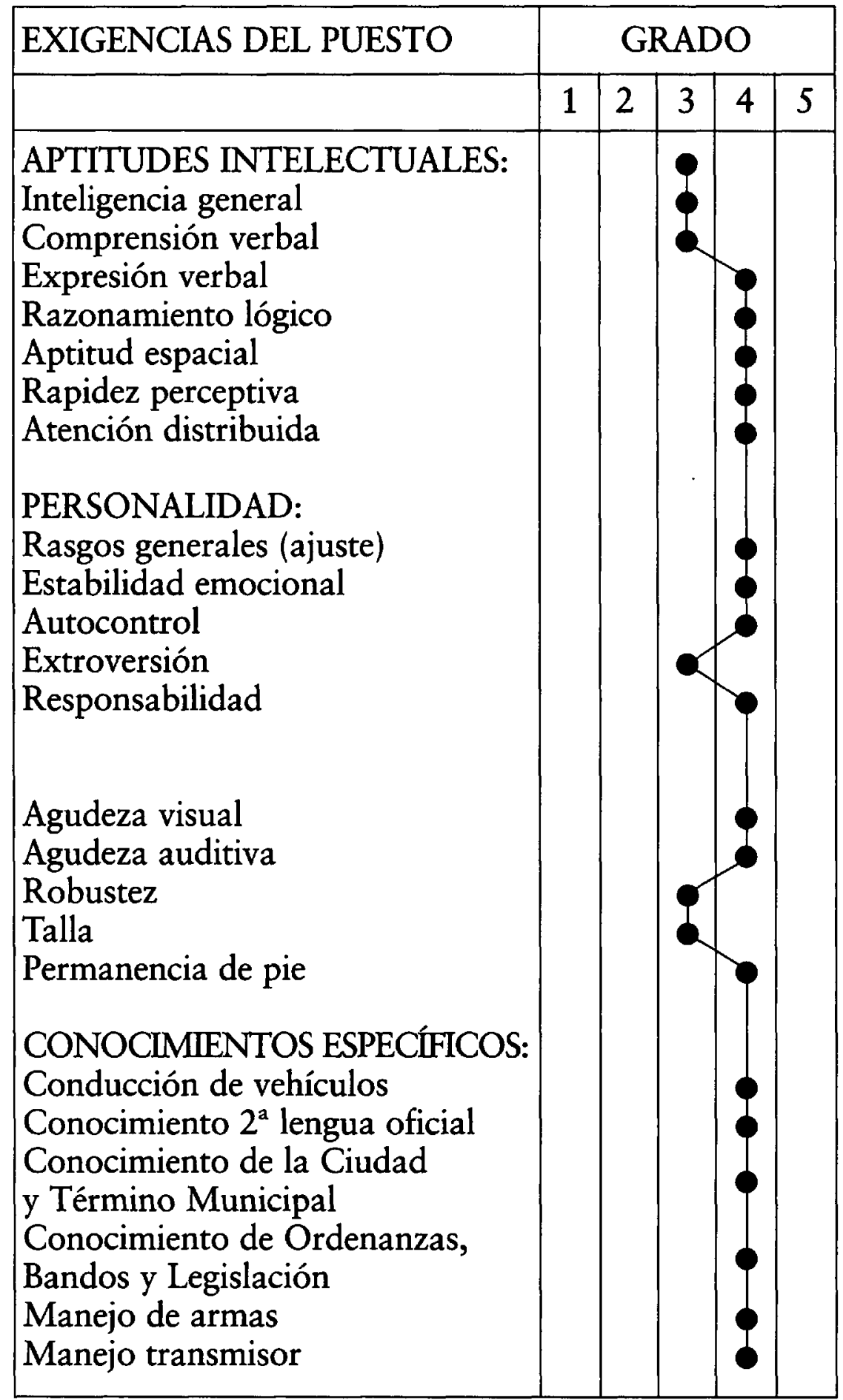


PROFESIOGRAMA DE UN ADMINISTRATIVO

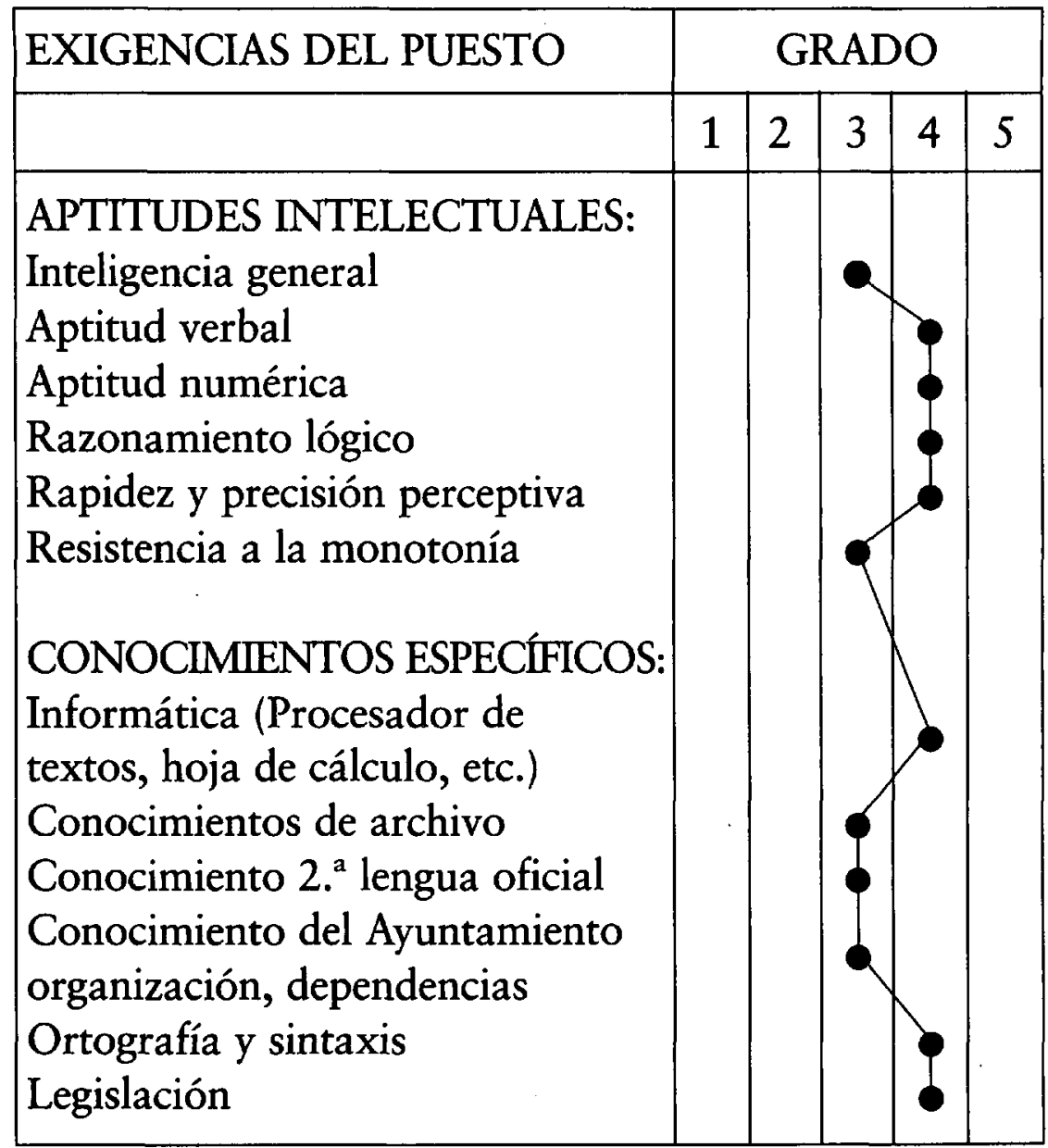

Tal y como recomienda el Grupo de Trabajo, estos profesiogramas son meros modelos orientativos, que deben ser empíricamente contrastados en función de la realidad y necesidades de cada Administración Local.

Sobre la aplicación de otros sistemas o técnicas valorativas, además de las entrevistas y los tests psicotécnicos, existe una variada gama de posibilidades que se utilizan en el sector privado, y sobre todo en el mundo anglosajón. A modo de ejemplo, nos parece interesante una sistematización de Claude LEVY-LEBOYER (1992, 163 y 164) sobre los diferentes métodos de evaluación a partir de tres criterios: su validez (aporta información fiable que nos ayuda a predecir la adecuación de la persona al puesto), su coste (incluye poner a punto unos métodos específicos y formar a los usuarios de los mismos) y su aceptabilidad 
(el hecho de que es fácil o difícilmente aceptable por los candidatos). Este es el cuadro sistemático que propone:

\section{VALIDEZ, COSTE Y ACEPTABILIDAD DE LOS MÉTODOS DE EVALUACIÓN}

\begin{tabular}{|l|c|c|c|}
\hline Método & Validez & Coste & Aceptabilidad \\
\hline Prueba profesional & Fuerte & Elevado & Muy buena \\
Test de aptitudes & Fuerte & Escaso & Buena \\
Seminarios de evaluación & Fuerte & Elevado & Muy buena \\
Test de funcionamiento cognitivo & Fuerte & Escaso & Buena \\
Biodata & Media & Medio & Buena \\
Referencias & Débil & Escaso & Muy buena \\
Entrevistas & Débil & Medio & Muy buena \\
Test de personalidad & Débil & Escaso & Escasa \\
Cuestionarios de interés & Débil & Escaso & Media \\
Autoevaluación & Débil & Escaso & Escasa \\
Grafología & Ninguna & Medio & Buena \\
\hline
\end{tabular}

En la Administración Pública española tras la aprobación de la reforma de 1984, y aún antes, se planteó la aplicación de diferentes técnicas de evaluación (CÁDIZ: 1984), pero tan sólo conocemos un intento de elaborar una metodología que se pudiera aplicar en los concursos de méritos para la provisión de los puestos con niveles más altos (del 26 al 29). En el año 1988 se creó una Comisión para el estudio de las provisiones de puestos de trabajo en las Administraciones Públicas, con el mandato de "estudiar, diseñar y proponer un sistema de provisión que garantice una gestión eficaz de los recursos humanos $y$ potenciar la profesionalidad de la Administración en que se encuadran estos recursos».

Esta Comisión, presidida por Don Manuel Elías Olarte, elaboró un proyecto que sirvió de base para redactar el Reglamento General de Provisión de Puestos del año 1990 (cuyo contenido reproduce el RGIPP de 1995), pero hubo un aspecto clave que se cambió en el último momento y que era el núcleo de la propuesta: un sistema de comprobación de los méritos y capacidades de los candidatos basado en unos ejercicios de simulación se sustituyó por las actuales memorias. Creemos que ésta es una de los principales causas del desprestigio del sistema actual de concurso específico, pues el Reglamento se limita a decir que "la memoria consiste, en su caso, en un análisis de las tareas del puesto y de los requisitos, condiciones $y$ medidas necesarias para su desempeño, a juicio del candidato, con 
base en la descripción contenida en la convocatoria» (Art. 45.4 RGIPP). En la práctica se ha distorsionado profundamente el uso de la memoria, porque no se utiliza como instrumento para comprobar y valorar los méritos específicos, sino que ella misma es valorada como un mérito específico más y éste otorga una puntuación concreta, o la memoria se utiliza más como mérito eliminatorio para acceder a la entrevista. Ignoramos las causas por las que se decidió sustituir la prueba escrita por la memoria, pero el resultado es un error que debería corregirse recuperando el planteamiento original. Nos parece importante explicar este otro modelo más acorde con los principios de mérito y capacidad, y que presenta una utilización de las pruebas escritas con un contenido ajeno a los tradicionales criterios memorísticos. Así funcionaría el sistema:

a) Elaboración de unos ejercicios de simulación, tanto genéricos como especializados, que traten de reproducir situaciones típicas del puesto. La simulación típica se basará en una matriz aproximada de 25 elementos que reproduzcan situaciones reales con las que se enfrentará el aspirante teórico del puesto. Cada uno de los elementos exigirá una decisión o actuación susceptible de ser apuntada, lo que permitirá objetivizar los resultados. Para ello, deberán seguirse las siguientes pautas en la construcción de supuestos:

- Que estén relacionados exclusivamente con el contenido del puesto y cubran todo su contenido.

- La parte más difícil de la prueba se conecte con lo más difícil del puesto.

- Sean diferentes para evitar la eventual repetición de pruebas a los mismos candidatos.

- Midan exclusivamente lo que hay que medir sin entrometerse en lo privado ni en aspectos de psicología profunda.

- Estén diseñados para que conduzcan a entrevistas bien planteadas y realizadas, ligadas al puesto, al perfil del mismo y a la descripción de trabajo.

- Sea fácil establecer normas de punteo en la entrevista y para el cómputo de la convocatoria.

- No pese la cultura del individuo, ya que no es un examen de conocimientos generales.

b) La Comisión de valoración procederá a efectuar una entrevista con cada aspirante, en la que se tratará de averiguar la motivación, enfoque y explicación de las respuestas formuladas por cada uno de ellos, así como la aclaración de determinados extremos del historial profesional. La entrevista se realizará sobre los elementos 
desarrollados en las pruebas escritas, de forma que el candidato exponga y defienda las soluciones que previamente ha redactado. Esta técnica ayuda a evitar los problemas de posibles filtraciones de las pruebas, porque no se trata de sólo saber resolver, sino de razonar y justificar.

c) Finalizado el proceso de provisión «hay que aplicar un seguimiento del trabajo desarrollado por el nuevo titular del puesto para comprobar la validez del sistema o detectar los posibles fallos que se hayan producido en su aplicación, para que puedan ser corregidos en sucesivas aplicaciones del mismo.

En conclusión, la posibilidad real de utilizar las mismas técnicas y métodos de evaluación en el sector privado y el sector publico hace que no podamos hablar de una especifidad importante que se concrete en una singularidad de la Administración Pública. La solución es la correcta utilización de cada técnica para el caso correspondiente, de tal manera que puedan superar un control judicial, tal y como sucede con normalidad en los países donde es tradicional su utilización. Por ello, lo importante es ser cautelosos y garantizar la objetivación de la técnica o método utilizados fundamentando su relación directa con el puesto o las funciones a desempeñar.

\section{SINGULARIDADES DERIVADAS DEL EJERCICIO DE LAS POTESTADES DE ORGANIZACIÓN POR LAS DIFERENTES ADMINISTRACIONES PÚBLICAS}

El ejercicio de las potestades de organización o de dirección, en la terminología clásica del Derecho del Trabajo, se fundamenta en el principio de eficacia (SANTAMARía PASTOR: 1984, 60 y 69). ¿Cuáles son las singularidades propias del empleador publico al ejercitar sus potestades? La respuesta esta condicionada por el logro del difícil equilibrio entre "el buen funcionamiento del servicio publico" y los "derechos de los funcionarios" o, dicho en términos más tradicionales, entre el interés de la organización y el interés del empleado (MARTíneZ Pison: 1993). Para identificar esas singularidades es necesario analizar los supuestos de movilidad forzosa y modificación de condiciones de trabajo en comparación con el empleador privado, pues es en estos supuestos donde el potencial conflicto de intereses puede aflorar con mayor intensidad, lo que obliga a sopesar los diferentes intereses que pugnan por inclinar el peso de una imaginaria balanza, en la que se contraponen los principios de eficacia y jerarquía con los de objetividad y mérito (FÉREZ: 1991). 


\subsection{Los supuestos de movilidad forzosa}

El poder de obligar a los empleados a cambiar de puestos pero manteniendo las mismas funciones (movilidad funcional) y de imponerle un cambio de puesto que implique cambio de residencia (movilidad geográfica) se da en el sector privado con mayor amplitud (arts. 39 a 41 del Estatuto de los Trabajadores, en adelante ET), pues se considera una de las claves de productividad y de competitividad al avanzar en la flexibilización de las relaciones laborales, hasta el punto de que el ejercicio de esa potestad puede conducir a la extinción del contrato. Mientras que en la función publica la regla general es la inamovilidad, que históricamente aparece como una garantía de profesionalidad e imparcialidad de los funcionarios frente a la arbitrariedad del poder, lo que en el caso español supuso la transición del decimonónico sistema de cesantías a un sistema de mérito al servicio de una Administración profesionalizada. Pero hoy en día parece necesario reinterpretar el alcance de la inamovilidad, pues se han producido cambios sustanciales en la propia función publica y la arbitrariedad ha sido sustituida por la discrecionalidad y ésta exige una motivación objetivada que es controlable jurisdiccionalmente (SANCHEZ MORÓN: 1996, 154). Por ello, nos parece que la singularidad del ejercicio de las potestades que implican movilidad forzosa de los funcionarios se concreta en dos únicos limites: el de la necesaria objetivación de la motivación legitimadora de la decisión y el de no poder conducir a la extinción de la relacion funcionarial (como sí puede suceder en el sector privado).

Veamos a continuación cómo se regulan los supuestos de movilidad forzosa en ambos sectores.

\subsubsection{Movilidad funcional con carácter definitivo}

En el sector privado la movilidad funcional constituye el "núcleo duro" de la potestad de dirección del empresario, que no necesita justificar su decisión, pues forma parte de su ius variandi (MONTOYA MELGAR: 1996, 419), y tiene como únicos límites el respeto de las titulaciones académicas o profesionales precisas para el desempeño del puesto y la pertenencia al grupo profesional o categoría profesional equivalente (art. 39.1 ET.) (MARTíNEZ ABASCAL: 1994; SALA FRANCO: 1994).

Frente a la sencillez de este planteamiento, en la Administración General del Estado, que tomaremos como modelo, nos encontramos con una regulación compleja, confusa y polémica, que evidencia las contradicciones de un sistema que es incapaz de articular un esquema de movilidad coherente. La explicación de esa complejidad y rigidez en el sector publico la podemos encontrar en que el actual sistema gira 
en torno al derecho al puesto, por lo que cualquier cambio se concibe como excepcional y «traumático», mientras que en el sector privado la referencia es la categoría o grupo profesional, con independencia del puesto.

Analizaremos las figuras previstas en el vigente Reglamento General de Ingreso del personal al servicio de la Administración General del Estado y de Provisión de Puestos de trabajo y de Promoción profesional de los funcionarios civiles de la Administración General del Estado, aprobado por Real Decreto 364/1995, de 10 de marzo (RGIPP):

A) La redistribución de efectivos (art. 59). El fundamento de este supuesto de movilidad obligatoria es "por necesidades del servicio" y presupone la existencia de una vacante que permite el traslado definitivo del funcionario. Los requisitos para poder realizar la redistribución son: que los puestos no sean singularizados («aquellos que no se individualizan o distinguen de los restantes puestos de trabajo en las correspondientes relaciones"), que sean de la misma naturaleza, que tengan el mismo nivel de complemento de destino y de complemento específico y que sean puestos que se cubran con el mismo procedimiento de provisión (se entiende que la regla general es el concurso de méritos). Sorprendentemente, el requisito de que la redistribución sea entre puestos de la misma naturaleza acaba de ser suprimido por la Ley 13/1996, de 30 de diciembre, (art. 103, apartado cuatro), lo cual supone una importante ampliación del ámbito de aplicación de este supuesto de movilidad forzosa. La redistribución no puede conllevar cambio de municipio porque entonces se convierte en un supuesto de movilidad voluntaria.

Esta figura se introdujo en el ámbito estatal mediante la Ley 23/1988, que modificaba la Ley 30/1984 (art, $20.1 \mathrm{~d}$ ), aunque la denominación proviene del Reglamento General de Provisión de Puestos del año 1985 (disposición adicional sexta), y se desarrolló en el Reglamento de 1990, que contenía una exigencia que el vigente RGIPP ha suprimido: la redistribución debía hacerse mediante resolución motivada. Nos parece que ésta es una exigencia ineludible, pues constituye una singularidad justificada en comparación con la potestad del empresario privado que no tiene que exteriorizar el origen causal de su decisión. Jurídicamente se puede reconducir la exigencia de motivacion explícita mediante la aplicación del art. 54 de la Ley 30/1992, de 26 de noviembre, de Régimen Jurídico de las Administraciones Publicas y del Procedimiento Administrativo Común, que impone la obligación de motivar los actos que se «dicten en el ejercicio de potestades discrecionales». También es cierto que este problema no se dará cuando la redistribución se fundamente en un Plan de Empleo previo (art. 2.1 RGIPP). La redistribución de efectivos tiene dos puntos oscuros: el concepto de puesto singularizado y la incógnita entre qué sucede y cómo se cubre 
el puesto que queda vacante al ser trasladado el funcionario titular (PAlomar: 1996). Es necesario clarificar estas dudas, pues sino existen muchas probabilidades de que en la práctica se desvirtúe su aplicación, con el correspondiente desprestigio de la que pretende ser la principal figura encauzadora de la movilidad funcional.

B) La reasignación de efectivos (art. 60). Estamos ante una figura de gran complejidad y especialmente polémica, que inicialmente conlleva movilidad funcional y puede conducir a la movilidad geográfica en las Administraciones de ámbito supramunicipal. La mecánica de funcionamiento es la siguiente: debe existir un Plan de Empleo previo que justifique la supresión de un puesto, y a partir de aquí se inicia un proceso para intentar recolocar al funcionario en un puesto de similares características, funciones y retribuciones, y si ello no es posible el funcionario pasa a la situación de excedencia forzosa con carácter indefinido (PALOMAR: 1995, 23).

La figura de la reasignación de efectivos se crea con la finalidad de servir para redimensionar los recursos humanos (pues también incluyen al personal laboral) posibilitando un trasvase de las áreas excedentarias a las áreas deficitarias. La reasignación debe realizarse "aplicando criterios objetivos relacionados con las aptitudes, formación, experiencia y antigüedad " (art. 60.1 RGIPP) que deberán concretarse en el correspondiente Plan de Empleo.

La reasignación de efectivos se inicia como un supuesto de movilidad funcional, tras un período de seis meses, pero se transforma en un supuesto de movilidad geográfica, que incluso puede conllevar un cambio de Administración si se formaliza el correspondiente convenio (art. 18.3 de la Ley 30/1984, según la redacción dada por la Ley $22 / 1993$, de 29 de diciembre).

Teniendo en cuenta que es en los supuestos de movilidad geográfica donde la reasignación desarrolla todos sus efectos, nos remitimos a ese punto para ampliar su explicación.

El supuesto de hecho de la reasignación de efectivos, la supresión del puesto de trabajo (sea o no singularizado), plantea un problema jurídico que podría desembocar en una singularidad de difícil justificación: ¿un Plan de Empleo es el único medio legal para la supresión de un puesto de trabajo? La respuesta podría ser afirmativa a la vista de la nueva regulación de la excedencia forzosa (art. 13 del Real Decreto $365 / 1995$, de 10 de marzo), que sólo contempla la posibilidad de acceder a la misma si se proviene de un proceso de reasignación de efectivos. Y la reasignación de efectivos, desde la entrada en vigor de la Ley 22/1993, sólo es posible previa la existencia de un Plan de Empleo que conlleva la supresión del puesto. Sin embargo, la respuesta debe ser negativa por tres razones: primera, porque, como veremos más adelante, existe otra figura que contempla como uno de los supuestos la 
supresión del puesto y no depende de un Plan de Empleo previo, es la adscripción provisional (arts. 63.2 y 72.3 RGIPP); segundo, porque aún está en vigor el art. 44.1 de la Ley Articulada de Funcionarios Civiles del Estado, que no puede considerarse estar modificado por el vigente Reglamento de situaciones administrativas (que debería haberse limitado a recoger el nuevo supuesto de excedencia forzosa aplicable a los funcionarios destinados en expectativa de destino, tal y como lo plantea la Ley 22/1993, y no presentarlo como un supuesto único, lo que supondría una limitación injustificada de la potestad organizativa porque no podría ejercerse directamente cuando implicara la supresión de algún puesto, ya que se necesitaría de un Plan de Empleo previo); y, tercera y última, porque el art. 15.1.d) de la Ley 30/1994 afirma que «La creación, modificación, refundición y supresión de puestos de trabajo se realizará a través de las relaciones de puestos de trabajo", por tanto, los Planes de Empleo también pueden implicar la supresión de un puesto, pero no siempre constituyen requisito previo.

En conclusión, la reasignación de efectivos como un supuesto de movilidad funcional puede calificarse de excepcional en cuanto a su motivación objetiva (existencia de un Plan de Empleo) pues se la iguala con los casos extremos de movilidad geográfica.

C) El cambio de adscripción del puesto (art. 61). Por razones organizativas se decide el traslado del puesto y del funcionario a otra unidad, centro o departamento, siempre que se trate de puestos no singularizados y la nueva adscripción no suponga un cambio de municipio, pues entonces se necesitaría la conformidad del titular del puesto (que también podría optar por la excedencia voluntaria incentivada, como ya veremos al analizar los supuestos de suspensión de la relación de servicio).

Este es un supuesto esencialmente idéntico a lo que sucede en el sector privado (con la excepción de la referencia a los puestos singularizados), donde un cambio de organigrama conlleva la readscripción de puestos y personas que siguen desempeñando las mismas funciones.

\subsubsection{Movilidad funcional con carácter provisional}

Esta es una modalidad que no se plantea el Derecho Laboral, puesto que el ius variandi del empresario (art. $39 \mathrm{ET}$ ) le permite realizar todos los cambios de puesto sin necesidad de explicitar la causa, siempre que respete las titulaciones y el grupo o categoría profesional, como ya hemos dicho anteriormente. Pero en las Administraciones Públicas existe una figura ya tradicional, la comisión de servicios forzosa, que implica la adscripción provisional a un puesto por razones de urgencia o situaciones excepcionales, cuya concreción ha ido 
variando en las diferentes regulaciones y con tendencia a ir transformando supuestos tradicionalmente voluntarios en obligatorios, ampliando de esta manera las potestades de comisiones por razones de eficacia. Además, al igual que sucede con la reasignación de efectivos, la comisión de servicios forzosa también puede conllevar la movilidad geográfica. Veamos los supuestos actualmente previstos en el RGIPP:

A) Necesidad de cubrir urgentemente una vacante cuyo concurso ha quedado desierto. La adjudicación se realizará de acuerdo con los siguientes criterios: un funcionario del mismo Departamento, que reside en el mismo municipio, o en el municipio más próximo o con mejores facilidades de desplazamiento y que tenga menores cargas familiares y, en igualdad de condiciones, el de menos antigüedad (art. 64.2). La comisión tendrá una duración inicial máxima de un año y podrá ser prorrogada por otro en caso de no haberse cubierto el puesto con carácter definitivo. Al funcionario se le reserva el puesto de trabajo y percibe unas retribuciones con cargo a los créditos dotados para el puesto que realmente desempeña.

B) Atribución temporal de funciones en los siguientes casos excepcionales: funciones especiales que no estén asignadas específicamente a los puestos incluidos en las relaciones de puestos de trabajo o realización de tareas que, por causa de un volumen temporal o por otras razones coyunturales, no puedan ser atendidas con suficiencia por los funcionarios que tengan asignadas dichas tareas (art. 66.1). La atribución de estas funciones deberá realizarse mediante resolución motivada que justifique la excepcionalidad y entendemos que en la misma debería fijarse cuál es el límite temporal que, paradójicamente, el RGIPP no contempla y que, por analogía, debería cifrarse en un máximo de dos años.

Estos dos supuestos de comisión de servicios forzosa pueden ser casos de movilidad geográfica, pero hay un tercer supuesto, la participación en misiones de cooperación internacional, que siempre lo es y que, por tanto, analizaremos al tratar de la movilidad geográfica.

En el sector privado estos supuestos de comisión de servicios forzosa se resuelven acudiendo a los diferentes modelos de contratos temporales, en el caso de que no fuera más adecuado acudir a un supuesto de movilidad geográfica temporal (el desplazamiento), que estudiaremos a continuación. Recordemos que en nuestra función pública algunos de estos supuestos de comisión de servicios forzosa eran objeto de los denominados contratos administrativos y de los interinajes, cuya proliferación y abuso hizo que la doctrina hablara de "función pública paralela» (JIMÉNEZ ASENSIO: 1989), a la que intentó poner fin la reforma de 1984 suprimiendo los contratos administrati- 
vos (disposición adicional cuarta de la Ley 30/1984), que siguen siendo objeto de discusión doctrinal y jurisprudencial (LOPEZ GÓMEZ: 1995, 231 a 238; GODINO REYES: 1996, 106 a 116).

\subsubsection{Movilidad geográfica}

La inamovilidad en la residencia, "siempre que el servicio lo consienta" (art. 63.2 de la Ley de 1964), es una de las garantías que tienen reconocidas los funcionarios y que históricamente tiene su reverso en el deber de residencia (art. 77.1 de la Ley de 1964). La inamovilidad de residencia como derecho se vincula al principio de imparcialidad en el desempeño del cargo (MARTINNEZ PISÓN: 1995), mientras que el deber de residencia se justificaba por el principio de eficacia, aunque la doctrina entiende que hoy sólo es exigible éste con carácter excepcional, pues supone una limitación al derecho constitucional a elegir libremente la residencia (art. 19). En el sector privado la movilidad geográfica también es concebida como una medida de especial gravedad, que cuenta con un procedimiento especial para su aplicación y que puede desembocar en la rescisión del contrato (art. 40 ET).

En ambos sectores se exige una fundamentación objetiva para adoptar medidas de movilidad geográfica, amparadas en principios de eficacia y eficiencia, y la diferencia se limita al proceso a seguir, que es más rápido y simple en la empresa privada, sin que por ello ofrezca menos garantías.

\section{A) En el sector privado}

Tras la reforma del Estatuto de los Trabajadores del año 1994 (Ley 11/1994), se entiende por traslado todo cambio geográfico cuya duración sobrepase los doce meses dentro de un período de tres años (art. 40.4 ET) y se ejerce en los siguientes términos:

- La decisión debe fundamentarse en razones económicas, técnicas, organizativas o de producción o en contrataciones referidas a la actividad empresarial. Y se entiende que concurren estas causas cuando la adopción de medidas de movilidad geográfica contribuyen «a mejorar la situación de la empresa a través de una más adecuada organización de sus recursos que favorezca su posición competitiva en el mercado o una mejor respuesta a las exigencias de la demanda» (art. 40.1 ET). La amplitud y ambigüedad de esta formulación hacen que la viabilidad de su aplicación dependa en gran medida del margen de apreciación de la prueba que corresponde a los tribunales de justicia, o de la capacidad del empresario de consensuar la medida. 
- Cuando el traslado es individual el empresario debe preavisar al trabajador y sus representantes legales con una antelación mínima de treinta días y éste puede adoptar tres actitudes: primera, aceptar el traslado y recibir una compensación por los gastos propios y de los familiares, que nunca sería inferior a los límites mínimos establecidos en los convenios colectivos; segunda, cumplir el traslado para impugnarlo ante la jurisdicción social, que en caso de que declare injustificado el traslado obligaría a reponer al trabajador a su puesto inicial; y tercera, rechazar el traslado y optar por la extinción del contrato, recibiendo indemnización de veinte días por año trabajado con un límite de doce mensualidades.

- Cuando el traslado es colectivo, por afectar a la totalidad de la plantilla o alrededor de un diez por ciento de la misma durante un período de noventa días, se deberán realizar los siguientes pasos: $1^{\circ}$ ) debe abrirse un período de consultas, que deberá ser notificado a la autoridad laboral, no inferior a quince días, para discutir con los representantes de los trabajadores las causas del traslado y la posibilidad de evitar o reducir sus efectos; $2^{\circ}$ ) finalizado el período de consultas, se le comunicará a la autoridad laboral y ésta, a instancia de los representantes de los trabajadores y cuando las consecuencias sociales o económicas lo justifiquen, podrá paralizar la efectividad del traslado por un período máximo de seis meses; y $3^{\circ}$ ) el empresario notificará a los trabajadores afectados la decisión del traslado con una antelación mínima de 30 días, y éstos podrán decidir en los términos expuestos para el traslado individual o también plantear un conflicto colectivo, lo que paralizaría todas las impugnaciones individuales hasta su resolución.

Al lado del traslado existe la figura del desplazamiento temporal, que se diferencia de aquel en cuanto a su duración (no puede exceder del plazo de doce meses en tres años) y en que no se distingue entre desplazamientos individuales y colectivos, pues ambos siguen exactamente el mismo procedimiento: el empresario les notifica su decisión, con una antelación mínima de cinco días si el desplazamiento es de duración superior a tres meses. El trabajador no puede optar, como en el caso del traslado, por la rescisión del contrato con una indemnización.

\section{B) En el sector público}

En las Administraciones Públicas la movilidad geográfica forzosa tiene una regulación bastante diferente. Como ya hemos visto anteriormente, las dos figuras que pueden conllevar cambio de residencia son la reasignación de efectivos y la comisión de servicios forzosa. 
Pero conceptualmente presentan importantes diferencias con la regulación del Estatuto de los Trabajadores. Por ejemplo, la reasignación de efectivos, que podría equipararse por su ámbito a los traslados colectivos (nos es muy difícil imaginar un Plan de Empleo previo que afecte a un solo funcionario) nunca puede obligar a aceptar un puesto que exceda del límite provincial donde reside el funcionario a reasignar, mientras que en el Derecho Laboral no existe este límite, como, por otro lado, tampoco existe cuando se utiliza la comisión de servicios forzosa (uno de cuyos supuestos es la participación en misiones de cooperación internacional -art. 65.1 RGIPP-).

No existe un procedimiento diferenciado si la movilidad geográfica. afecta a un solo funcionario o un colectivo. Tampoco hay coincidencia en cuanto a los plazos: la reasignación de efectivos lo es con carácter indefinido y la comisión de servicios puede tener diferentes límites temporales (el máximo puede ser de seis meses o de dos años, o indeterminado, dependiendo de la causa motivadora). Una gran diferencia es que no sirven las mismas causas para justificar la reasignación de efectivos ("la óptima utilización de los recursos») y las comisiones de servicios forzosas (cobertura de vacante cuyo concurso ha quedado desierto, participación en una misión de cooperación internacional por el plazo máximo de seis meses - pues por encima de este plazo es una situación de servicios especiales- $o$ atribución temporal de funciones).

Si buscamos analogías entre los traslados colectivos y los procesos de reasignación de efectivos podemos señalar al menos tres. Primera, los Planes de Empleo que componen la reasignación deben ser objeto de negociación con los representantes sindicales, al igual que los traslados colectivos. Segunda, los funcionarios afectados por un proceso de reasignación pueden optar por una indemnización que es idéntica a la prevista en los traslados laborales si se opta por la extinción del contrato (un mes por año trabajado con el límite de doce mensualidades), pero el funcionario no extingue su relación sino que la suspende pasando a la situación de excedencia voluntaria incentivada durante cinco años (art. $18 \mathrm{RGIPP}$ ). Y tercera, razones organizativas y razones económicas pueden ser causas comunes a los traslados colectivos y a la reasignación de efectivos, pues recordemos que la principal clase de Plan de Empleo, los Planes Integrales de Recursos Humanos, "especificará los objetivos a conseguir en materia de personal, los efectivos $y$ la estructura de recursos bumanos que se consideren adecuados para cumplir tales objetivos, las medidas necesarias para transformar la dotación inicial en la que resulte acorde con la estructura de personal que se pretenda» (art. 2.1. RGIPP).

Hay una cuestión de fondo que convierte realmente en excepcional la reasignación de efectivos en las Administraciones Públicas: la tremenda complejidad, enorme lentitud y potencial conflictividad que 
implica la elaboración y puesta en marcha de un Plan de Empleo. Recordemos cuál es el proceso (Palomar: 1995, 22, 23):

- La iniciativa puede partir del Ministerio u Organismo afectado, o, conjuntamente, a los Ministerios para las Administraciones Públicas y de Economía.

- El proyecto de Plan de Empleo se debe negociar con las Organizaciones Sindicales, tomando como base la Memoria justificativa de las medidas concretas que contempla el Plan.

- El Ministerio de Economía y Hacienda deberá emitir informe favorable para la aprobación del Plan.

- El Secretario de Estado para la Administración Pública aprueba el Plan de Empleo y éste se publica en el Boletín Oficial del Estado.

- Se inicia el proceso de reasignación de efectivos, que implica la modificación de las relaciones de puestos de trabajo para la correspondiente supresión de determinados puestos, y se notifica a los afectados que se intentará recolocarlos mediante un proceso que puede durar 21 meses estructurados en las siguientes fases:

1) Durante seis meses se les intentará reasignar en algún puesto del mismo Departamento y de los Organismos adscritos. Si el puesto es de similares características, funciones y retribuciones al puesto originario y se encuentra en el mismo municipio deberá aceptar obligatoriamente la reasignación, pero si implica cambio de municipio puede rechazar el puesto y continuar en servicio activo y percibiendo las retribuciones del puesto de trabajo suprimido que desempeñaba, o puede optar por acogerse a la excedencia voluntaria incentivada.

2) Durante los tres meses siguientes puede ser reasignado a otro Departamento ministerial en las mismas condiciones y con los mismos limites de la primera fase.

3) Durante un período máximo de doce meses los funcionarios que no hayan obtenido un puesto de trabajo se adscriben al Ministerio para las Administraciones Públicas a través de relaciones específicas de puestos de reasignación. En esta fase es obligatorio aceptar cualquier puesto de similares características (que ahora se restringe a la provisión y retribuciones, suprimiendo la referencia a las funciones) dentro del ámbito provincial, pues fuera de éste es voluntario. Al funcionario se le declara en esta fase en situación de expectativa de destino, en la que cobrará las retribuciones básicas y la mitad del complemento específico de su anterior puesto y tiene la obligación de participar en los concursos y cursos de capacitación que se le notifiquen. Puede solicitar la excedencia voluntaria incentivada.

4) Pasan a la situación de excedencia forzosa con carácter indefinido. Percibirán solamente las retribuciones básicas y las prestacio- 
nes familiares por hijo. Tienen las mismas obligaciones que en la situación de expectativa de destino. Pueden solicitar la excedencia voluntaria incentivada.

La enorme complejidad de este proceso puede explicarse por dos razones: el origen de los Planes de Empleo y su potencial incidencia en los derechos de los empleados afectados (recordemos que pueden ser tanto funcionarios como laborales). Los Planes de Empleo surgen en un contexto de crisis económica en el que se plantean medidas duras de reforma del mercado laboral y se pretende controlar el déficit público; de esta manera los Planes de Empleo se presentan como un instrumento racionalizador para la gestión de los recursos humanos en las Administraciones Públicas, siendo concebido como el mecanismo que deberá ayudar a controlar y redimensionar las plantillas de empleo públicas, mediante medidas de reducción y congelación de plantillas y de redistribución y reasignación de efectivos. La conclusión es que los Planes de Empleo aparecerían como una medida excepcional que respondía a una situación de grave crisis económica. Pero este planteamiento inicial experimenta un giro copernicano con la firma del Acuerdo Administración-Sindicatos para el período 1995-97, sobre condiciones de trabajo en la Función Pública (aprobado por el Consejo de Ministros el 16 de setiembre de 1994): los Planes de Empleo se configuran como el «instrumento estratégico de planificación integral de los recursos humanos a través de la racionalización y simplificación de la estructura ocupacional de cada sector de la Administración» (punto 4 de la Introducción del Acuerdo). Esto significa que los Planes de Empleo deberán convertirse en el soporte de las políticas de personal y de sus procesos de gestión (capítulos X, XI y XII del Acuerdo). Con este giro copernicano, los Planes de Empleo pasan de ser una figura excepcional a representar la regla general, como se plasma en la Oferta de Empleo Público para el año 1995 (RD 700/95, art. 3) y en el nuevo RGIPP del año 1995, que ahora los dividirá en Planes Integrales de Recursos Humanos y Planes Operativos de Recursos Humanos (art. 2.2). Con este nuevo planteamiento los derechos tradicionales de los funcionarios, especialmente el derecho al cargo y el derecho a la carrera, quedan claramente subordinados al interés de la organización, por lo que se intenta que los Planes de Empleo se elaboren con el máximo de consenso y con las suficientes garantías de objetividad, lo que se busca mediante el complejo proceso de elaboración y aplicación que hemos descrito.

Nuestra conclusión es que la actual regulación de la movilidad geográfica de los funcionarios, ya sea mediante las comisiones de servicios forzosas o a través de los procesos de reasignación de efectivos, debería replantearse a fondo y plasmarse en una fórmula que de forma más clara y sencilla objetive la excepción a la inamovilidad en la residencia 
porque el servicio no lo consienta (en la terminología del art. 63.2 de la Ley 1964). Posiblemente en esta línea podrían avanzar más fácilmente las Comunidades Autónomas y, especialmente, las Administraciones Locales, utilizando para ello la habilitación que les otorga la nueva regulación de la Ley 30/1984 (disposición adicional vigésimo primera), que les permite diseñar sistemas alternativos a los Planes de Empleo para conseguir las mismas finalidades; aunque nos tememos que se caiga en la tradicional inercia de reproducir las actuaciones estatales.

Como resumen final podemos decir que la única singularidad que justifica la diferenciación del régimen de movilidad geográfica en el sector público es que ésta nunca puede conducir a la extinción de la relacion funcionarial, pues como máximo puede conducir a la situación de excedencia forzosa, si es que el afectado no ha optado por la excedencia voluntaria incentivada o por la jubilación anticipada incentivada.

\subsection{Modificación de las condiciones de trabajo}

La modificación de las condiciones de trabajo las clasificamos en dos grandes grupos: las que se refieren a cambios en el contenido de las funciones y las relacionadas con las circunstancias concretas en que se ejercen esas funciones. Esta clasificación tiene como única finalidad poder realizar un análisis comparativo del ejercicio de determinadas potestades de organización o de dirección, tanto desde la perspectiva de su fundamentación como del procedimiento y de los límites que en cada caso deben respetar.

\subsubsection{Cambios en el contenido de las funciones}

A la hora de analizar los diferentes supuestos en el sector público y en el sector privado hemos de recordar que en un caso el criterio delimitador de la función es el puesto mientras que en el otro lo es la categoría o grupo profesional; pero en ambos casos se exige una fundamentación objetiva del cambio, que puede ser definitivo o provisional.

\section{A) Cambios definitivos}

Las principales diferencias entre el sector público y el privado las encontramos en las consecuencias del cambio y en el procedimiento para tomar la decisión, pues las causas son esencialmente coinciden- 
tes: organizativas y económicas (a las que podría añadirse, en la terminología del art. $41 \mathrm{ET}$ : técnicas y de producción). La alteración sustancial de funciones es un concepto jurídico indeterminado, que en el Derecho laboral se introduce en la reforma del año 1994, y que se concreta en la exigencia de unos requisitos diferentes de los inicialmente exigidos para el desempeño del puesto, hasta el punto de poder llegar a imponer el cese de su titular, y también se define por oposición a los supuestos de movilidad funcional ordinaria (art. 39.5 ET). Esta alteración sustancial de funciones en el sector privado puede tener las siguientes consecuencias:

a) El empleado entiende que el cambio de funciones redunda en "periuicio de su formación profesional o en menoscabo de su dignidad» (art. 50.a ET) y solicita la rescisión del contrato con derecho a la misma indemnización que la señalada para el despido improcedente (cuarenta y cinco días de salario por año de servicio con un límite de cuarenta y dos mensualidades).

b) La empresa ofrece al trabajador un curso de reconversión o de perfeccionamiento profesional que le capacite para la adaptación requerida (art. 52.b ET). El contrato queda en suspenso durante ese período (como máximo tres meses) y se le abona al empleado el salario medio que viniera percibiendo.

c) Transcurridos dos meses desde las modificaciones operadas en el puesto de trabajo, "cuando dichos cambios sean razonables» (art. 52.b ET) la empresa plantea la extinción del contrato por falta de adaptación del trabajador. Según la doctrina, "la operación de la razonabilidad del cambio tiene un estrecho margen, ya que el art. 39.3 ET niega el carácter de causa objetiva de despido a la falta de adaptación (y a la ineptitud) como consecuencia de la movilidad funcional» (MONTOYA: 1996, 477). La empresa debe indemnizar al trabajador con veinte días por año de servicio y con un límite de doce mensualidades.

En el sector público la alteración sustancial de funciones también tiene importantes consecuencias:

a) Puede conllevar el cese en el puesto de trabajo obtenido mediante concurso de méritos (art. 20. l.e LMRFP) cuando hay una modificación de los supuestos que sirvieran de base a la convocatoria y el funcionario es adscrito provisionalmente a otro puesto, a la espera de un destino definitivo, y durante tres meses tiene garantizadas las retribuciones complementarias de su anterior puesto (art. 21.2.b LMRFP).

b) Puede ser redistribuido a nuevo puesto de similares características en caso de que exista vacante, acompañando esta medida con "las acciones de formación precisas para el desempeño adecuado" de 
nuevo puesto (art. 4.1 del Real Decreto 700/95, de 28 de abril, por el que se aprueba la oferta de empleo público para 1995).

c) Si la alteración sustancial es consecuencia de un Plan de Empleo puede entrar en un proceso de reasignación de efectivos, que le conducirá a la recolocación, o la situación de excedencia forzosa, como ya vimos anteriormente al explicar este proceso, pudiendo optar también por la excedencia voluntaria incentivada o por la jubilación anticipada incentivada (si reúnen los requisitos exigidos - art. 34 LMRFP-).

La diferencia principal entre ambos sectores es que en el sector privado el cambio sustancial en el contenido de las funciones puede conllevar la extinción del contrato (por iniciativa de la empresa o del propio trabajador), mientras que el funcionario público no extingue su relación de servicio, sino que puede suspenderse indefinidamente por decisión de la Administración (excedencia forzosa) o suspenderse provisionalmente por iniciativa del funcionario (excedencia voluntaria incentivada durante cinco años); en otras palabras, técnicamente estaríamos contraponiendo una pérdida del puesto que conlleva la extinción de la relación frente a otra pérdida del puesto que conlleva la suspensión de la relación y la extinción del derecho al cargo sobre puesto concreto. Y también podemos señalar dos analogías: la importancia de la formación para posibilitar la readaptación al cambio de funciones (que creemos deberia configurarse como preceptiva en ambos sectores) y la posibilidad de que el trabajador o funcionario pueda optar por una salida con una indemnización similar (aunque el segundo tenga garantizado el retorno en el plazo de cinco años).

En cuanto a los procedimientos a seguir para introducir esos cambios sustanciales en las funciones, nos hemos de remitir en gran parte a lo dicho al tratar de los supuestos de movilidad forzosa, con las siguientes matizaciones. En el Derecho laboral se parte de las mismas causas que para la movilidad geográfica y se mantiene la distinción de procedimiento cuando es individual o colectiva, pero esa distinción ahora se hace más compleja, pues no se basa solamente en criterios cuantitativos (art. 40.2 ET) sino también cualitativos: se consideran modificaciones colectivas las reconocidas en un acuerdo o pacto colectivos (convenio extraestatutario) o en una decisión empresarial con efectos colectivos y se consideran modificaciones individuales aquellas condiciones de trabajo que se disfrutan a título individual (art. 4.1.2. ET). Esto supone que pueden darse modificaciones que afecten a sólo una persona y tengan que tramitarse por el procedimiento colectivo y al reves, que aunque las modificaciones afecten a varias personas se tramiten por el procedimiento individual al no tener origen en una fuente colectiva. 
En el Derecho Administrativo el instrumento normal para proceder a la modificación de las funciones de puestos es la relación de puestos de trabajo (art. 15.l.d LMRFP), pero puede tener su causa en la existencia previa de un Plan de Empleo (art. 18.2.a. LMRPF) en cuyo caso el procedimiento se complica bastante, como ya vimos al exponer supuestos de movilidad forzosa. Estos instrumentos tienen en común con el procedimiento colectivo del Derecho Laboral que también deben ser objeto de negociación con los representantes sindicales (ALDOMA: 1996 b).

\section{B) Cambios provisionales}

La alteración temporal de las funciones es objeto de una regulación más detallada en el sector privado que en el sector público.

En el Derecho Laboral podemos distinguir entre:

1) Cambios fruto de la potestad de movilidad funcional extraordinaria del empresario, que se produce fuera del grupo profesional o entre categorías no equivalentes. El ejercicio de esta potestad del empresario se debe fundamentar explícitamente en razones técnicas u organizativas y su duración debe limitarse al tiempo imprescindible (art. 39.2 ET). Si se encomiendan funciones inferiores deben justificarse en necesidades perentorias o imprevisibles de la actividad productiva y debe comunicarse la situación a los representantes de los trabajadores; el trabajador mantendrá su retribución de origen (art. 39.3 ET). Y si se encomiendan funciones superiores el límite temporal es de seis meses durante un año $u$ ocho meses durante dos años, pues superados estos períodos se entenderá que el trabajador puede reclamar el ascenso, salvo que por convenio colectivo o por las reglas aplicables en la empresa se establezca un régimen diferente (art. $39.4 \mathrm{ET}$ ); en cualquier caso el trabajador tendrá derecho a la retribución de las funciones que efectivamente realice.

En estos supuestos de movilidad extraordinaria también son aplicables los límites de la movilidad funcional ordinaria: no puede haber menoscabo de la dignidad del trabajador, no puede perjudicarse su formación y promoción profesional y el empresario no podrá invocar la ineptitud sobrevenida o la falta de adaptación. a esas nuevas funciones como causas de despido objetivo (art. 39.3 ET).

2) Cambios resultado de la modificación sustancial de las funciones, cuya duración no excede de noventa días y que se fundamentan en razones económicas, técnicas, organizativas o de producción (art. 41.2 ET).

Se distingue entre un procedimiento individual (siempre que el numero de trabajadores éste por debajo de un tanto por ciento legal- 
mente establecido) y un procedimiento colectivo, que son esencialmente idénticos a los establecidos en los supuestos de movilidad geográfica.

En el Derecho Administrativo los cambios provisionales de funciones se realizan mediante las comisiones de servicios forzosas o las denominadas adscripciones provisionales, a las que nos hemos referido anteriormente al tratar de los supuestos de movilidad forzosa. Los límites de las funciones atribuibles se establecen en relación con los Cuerpos o Escalas en que se encuadran los funcionarios, y dentro de éstos en relación con la horquilla de niveles que corresponde a un grupo de titulación, dentro del cual se le pueden atribuir funciones correspondientes a los niveles superiores o a los inferiores (aunque hasta el año 1988 existía una previsión legal expresa que estableció esos límites en dos niveles por arriba y dos por abajo, pero ahora este límite inferior está reservado para los funcionarios que cesen en su puesto por alteración de su contenido o supresión del mismo en las correspondientes relaciones de puesto de trabajo - art. 72.3 RGIPF). En esa alteración de funciones lo único que tiene garantizado todo funcionario es el complemento de destino correspondiente a un grado personal (art. 22.2 LMRFP), y luego según el sistema de atribución provisional de funciones se le garantiza uno $u$ otro nivel retributivo.

\subsubsection{Cambios en las condiciones en el ejercicio de las funciones}

La fijación unilateral de las condiciones de trabajo y su modificación es una de las potestades tradicionales de las Administraciones Publicas en relación con sus funcionarios, y jurídicamente se fundamentaba en la teoría de las relaciones de sujeción especial, (LÓPEZ BENITEZ: 1994). Esa potestad de determinación hoy en día se encuentra modulada por la obligación de negociar previamente su adopción con los representantes sindicales, como exige la Ley 9/1987, de 12 de junio, sobre Organos de representación, determinación de las condiciones de trabajo y participación del personal al servicio de las Administraciones Públicas (LORDP) y como desarrollan los Acuerdos Administración del Estado-Sindicatos para los períodos 1992-1994 y 1995-1997. Este giro copernicano aproxima el modelo funcionarial al modelo laboral; pero una vez establecido el marco general cada sector tiene sus especificidades a la hora de adoptar modificaciones concretas (REY GUANTER: 1989).

En el Estatuto de los Trabajadores se establece el siguiente modelo de modificación sustancial de las condiciones de trabajo (art. 41). En primer lugar se reconocen las mismas causas legitimadoras que para los supuestos de movilidad forzosa (razones econó- 
micas, técnicas, organizativas o de producción). En segundo lugar, se identifican unas materias concretas (la lista no es cerrada) que por su importancia se consideran relevantes en las condiciones de trabajo: la jornada, el horario, los turnos, el sistema de remuneración, el sistema de trabajo y de rendimiento y las funciones (que se añadieron en la reforma del año 1994 y cuyo análisis específico hemos realizado en el epígrafe precedente). En tercer lugar, se mantiene la distinción entre el procedimiento individual y el colectivo, con las matizaciones que hemos expuesto al explicar los cambios definitivos de funciones. En cuarto lugar, si el trabajador resulta perjudicado por la modificación de la jornada, el horario o el turno tiene derecho a rescindir el contrato y a recibir una indemnización de veinte días de salario por año trabajado con un máximo de nueve meses (art. 41.3 ET), y si considerase que esos cambios repercuten en perjuicio de su formación profesional o de su dignidad puede plantear la rescisión del contrato con derecho a la indemnización correspondiente a un despido improcedente (art. 50.a ET). En los demás casos, si considera injustificadas las modificaciones las puede impugnar ante la jurisdicción competente.

En las Administraciones Públicas no existe ni una identificación tasada de las materias relacionadas con las modificaciones sustanciales de las condiciones de trabajo, ni un procedimiento específico. La relevancia de las modificaciones estaría en función de si conlleva un cambio en la relación de puestos de trabajo, donde aparecen identificados los elementos retributivos y las especificidades que pueda tener el puesto en cuanto a jornada u horario diferente al establecido con carácter general (art. 12 de la Orden Ministerial de 6 de febrero de 1989). Los criterios generales en cuanto a jornada, horarios, vacaciones, permisos y licencias se establecen por una Resolución de la Secretaría de Estado para la Administración Pública (la vigente es de 27 de abril de 1995) previa negociación con las Organizaciones Sindicales $y$, posteriormente, se procede a concretar su aplicación en cada Departamento y organismo mediante aprobación del denominado calendario laboral, que también es objeto de negociación. El resto de materias deben ser objeto de negociación cuando se pueden encuadrar en el controvertido art. 32 de la LORDP, cuyo límite teórico son las potestades de organización.

En conclusión, el cambio de condiciones en el ejercicio de funciones podría ser esencialmente coincidente en el sector público y en el privado, con la única matización de que en el sector público habría que clarificar el ámbito material, pues actualmente es confusa la línea que separa el ejercicio de las potestades organizativas que se ejercen unilateralmente de aquellas que implican decisiones que deben ser objeto de negociación. 


\section{ALGUNAS REFLEXIONES SOBRE LA NECESARIA RENOVACIÓN DEL ACTUAL SISTEMA DE EMPLEO PÚBLICO}

\section{EL RETO DE NO REPETIR ERRORES HISTÓRICOS}

El actual modelo de empleo público español se encuentra en una encrucijada. Por un lado, se mantienen y consolidan lastres históricos que ponen de manifiesto la ausencia de un norte claro en las diferentes reformas que tienen lugar desde el año 1984. Por otro lado, se importan conceptos y técnicas descontextualizadas del modelo que se copia y, por tanto, condenados al fracaso cuando no es posible reproducir las condiciones que deberían posibilitar su implantación. Es notorio que esa mixtificación de modelos, que ya se inició con el tecnocratismo de los años sesenta, ha fracasado, entre otras razones, por los siguientes:

$1^{\circ}$ ) Era una reforma autocualificada de "parcial y provisional" a la espera de una formulación global, que ha sido sustituida por una sucesión de "reformas-parche" que reinciden en los mismos errores técnicos y abundan en el desprestigio del sistema, pues sus posibles aciertos quedan sepultados por su desvirtuación práctica.

$\left.2^{\circ}\right)$ Se sigue reproduciendo el error histórico de no abordar previamente una verdadera reforma organizativa en la que incardinar el modelo público de empleo al servicio de una política de personal coherente (LONGO: 1995, 14).

$\left.3^{\circ}\right)$ No existe el imprescindible apoyo político para su puesta en marcha, produciéndose un flagrante divorcio entre el discurso retórico de la modernización y las medidas concretas que deben hacerlo realidad, hasta el punto de constatarse una situación de auténtica esquizofrenia entre el discurso oficial y lo que se publica en el BOE.

Siendo justos hemos de constatar que la encrucijada no sólo lo es del modelo de empleo público, sino también del modelo de Estado y de la Administración que le sirve, así como de la concepción jurídica que subyace a los mismos. Con esto queremos poner de relieve que no se puede abordar una verdadera refundación del empleo público si no se enmarca en el debate sobre modelo de Estado, vinculado al papel que hoy en día se otorga a las Administraciones Públicas en relación con la sociedad y se revisan las concepciones jurídicas que la articulan a la luz de las nuevas necesidades. Es decir, partimos de un modelo de empleo público que hunde sus raíces en los finales del siglo XIX y hemos de plantearnos qué cambios son imprescindibles para encarar el nuevo siglo XXI. Es cierto también que éste no es un problema 
exclusivo de nuestro país, ni tan sólo del sector público, pero ello no es atenuante de la gravedad del diagnóstico y debe ser un objetivo poder equipararnos a otros países de nuestro entorno que están afrontando este mismo reto.

Ante esta situación es especialmente relevante la metodología con la que se aborda una verdadera reforma en profundidad. La tentación inicial es reproducir el esquema de comportamiento del año 1984: identificar proceso de reforma con cambio de marco jurídico, eso sí, no reproduciendo el error de hablar de marco provisional sino presentarlo como el «esperado" Estatuto de la Función Pública. Para este proceso la metodologia tradicional consiste en hacer que el Ministerio del ramo elabore un texto jurídico apoyándose en cualquiera de los borradores preexistentes, afinados técnicamente por algunos funcionarios de confianza y pseudo-legitimados con informes y dictámenes de juristas y expertos, cuyo nombre es debidamente invocado ante cualquier ataque a la idoneidad técnica del texto, y todo ello rematado por una bien «comprada» paz sindical tras unas «duras» negociaciones, que deberán ser paralelas a las entabladas con grandes cuerpos de funcionarios con influencia en los aledaños gobernantes.

Por contra, si se supera esta tentación inicial, la metodología de una reforma en profundidad puede seguir otros derroteros: empezar por plantear la reforma del sector público como una prioridad impulsada desde el máximo nivel político; seguir por elaborar un diagnóstico riguroso y fiable (una especie de Libro Blanco del Sector Público) en el que fundamentar unas propuestas técnicamente coherentes; y continuar con la apertura de un gran debate político y social, en el que tengan voz todos los agentes políticos, económicos y sociales y se contrasten alternativas, como ha sucedido, por ejemplo, cuando se ha planteado la reforma del mercado laboral. El instrumento adecuado puede ser una Comisión que combine legitimidad técnica y política en la línea de lo que han hecho o están haciendo otros países de nuestro entorno. Por último, parte del resultado de ese gran debate se debería concretar en un nuevo marco jurídico. La opción por una u otra metodología nos parece una decisión política clave para calibrar el alcance de la reforma y saber si estamos ante una "reforma de papel» (NIETO: 1989, 130) o ante una verdadera reforma (ECHEBARRIA: 1993).

\section{LA REVISION DE ALGUNOS CONCEPTOS E INSTITUCIONES BÁSICOS}

La renovación del sistema de empleo público debe hacer frente a la crisis de una serie de conceptos e instituciones básicas, ya sea porque se han convertido en anacrónicas o porque debe revisarse su conteni- 
do y funcionalidad. A continuación analizaremos algunas de las ideas e instituciones más significativas de nuestra función pública.

\section{A) La reformulación del contenido sustantivo de las ideas de mérito y capacidad}

La forja del binomio "mérito y capacidad" tiene sus orígenes en el siglo XIX, concretamente en un Real Decreto de López Ballesteros en 1827, y es recogido en casi todas las Constituciones desde la de 1837 hasta la actual de 1978, adelantándose en casi un siglo a la formulación de igualdad con rango constitucional (1931). En Francia se consolida el término "capacidad" formulado en la Declaración de Derechos del Hombre y del Ciudadano en 1789 y en los Estados Unidos de Norteamérica se fragua la idea del «sistema de mérito» a partir de 1883. Pero una vez instaurado el sistema de mérito, y con independencia de que el modelo adoptado sea el de carrera o el de empleo, la historia ha pasado factura a los tres países por el deterioro de una concepción ya centenaria. Jacques ZILLER nos recordaba que «si existe una ambigüedad en relación con la palabra discriminación, también la hay sobre la palabra mérito, y posiblemente con consecuencias más importantes». DE LA CRUZ FERRER (1984), en relación con Estados Unidos, afirmaba que "podemos decir que la concepción originaria del sistema de mérito se ha ido diluyendo y se ha generado una concepción bastante vaga de lo que el sistema de mérito actualmente significa o representa", y apostillaba, "esta falta de concreción puede detectarse incluso en los estudios académicos sobre el particular». En el año 1978 Estados Unidos actualiza los principios del sistema de mérito y concreta el contenido sustantivo de la idea de mérito en la valoración de conocimientos, aptitudes y habilidades (KSA: Knowledges, Skills, and Abilities). Por contra, en Francia y España se encadenan reformas legislativas, algunas cronológicamente posteriores, que se muestran incapaces de propiciar el avance cualitativo que la sociedad le demanda a las Administraciones Públicas en la articulación de sus recursos humanos, de tal manera que las rémoras históricas se convierten en un lastre que acaba ahogando cualquier voluntarioso intento de introducir mejoras o, en el mejor de los casos, quedan como islotes insignificantes en el inabarcable archipiélago de las Administraciones Públicas.

La Constitución de 1978 ha servido para otorgar a la fórmula rituaria del mérito y la capacidad una función principal como parámetro de constitucionalidad del derecho fundamental de acceso en igualdad de condiciones. Sin embargo, desde el punto de vista de su contenido, los poderes públicos, ya sea por falta de voluntad o por incompetencia, han desactivado lo que de positivo podía tener la 
reforma de 1984 para propiciar una reformulación del contenido de esa fórmula histórica, y con ello contribuyen al apuntalamiento de un muro hecho de confusión e incertidumbre que, al mismo tiempo, dificulta gravemente el cumplimiento de su papel de parámetro constitucional. Y cuando se intenta una reflexión en profundidad sobre este hecho se descubre que, en la etapa postconstitucional, se ha consolidado un fenómeno de profundas raíces históricas: lo podemos describir como el secuestro de las ideas de capacidad y mérito por los instrumentos para su valoración, ya se haga ésta de forma independiente, mediante la oposición y el concurso, o de forma conjunta, mediante el concurso-oposición.

MORELl OCAÑA (1994) ha identificado como principal causa de la falta de credibilidad social del sistema de mérito la distancia que existe entre el mérito y la idoneidad para el ejercicio de la función pública. Esa distancia tiene mucho que ver con el sistema de valoración del candidato, de ahí que normalmente el debate de los sistemas de selección haya ocultado un verdadero debate de fondo sobre el perfil e idoneidad de los candidatos. En efecto, como nos señala este autor, el actual sistema de mérito impone un proceso de selección en el que no se selecciona al mejor para el desempeño de la función sino al «más preparado", pero en base a una preparación que está lejos de la idoneidad profesional, pues no se escoge al que tiene «el mejor dominio de un saber sino la memorización sistemática y la exposición esquemática del mismo». Esta concepción del mérito conduce a dos importantes limitaciones: la primera es el rechazo a valorar aptitudes naturales, tan sólo cuentan las aptitudes adquiridas mediante el propio esfuerzo, "se prescinde de la mayor idoneidad que pudiese resultar de la condiciones naturales de cada uno"; $y$ la segunda limitación es que "raramente el sistema de pruebas de acceso toma en cuenta la distancia que media entre el título académico y la especialidad profesional» (MORELL: 1994, 164). La consecuencia de esas limitaciones es precisamente la reticencia en admitir técnicas selectivas contrastadas en el sector privado, como las entrevistas o los tests psicotécnicos, y la excepcionalidad en admitir la experiencia profesional en la fase de acceso. Por suerte, hay alguna Comunidad Autónoma, como es el caso de Cataluña, que ha incorporado la idea de «idoneidad» en la definición de la oposición, $y$ lo reitera para identificar la finalidad que debe tener la entrevista que se pueda prever en esa misma fase de oposición (arts. 37 y 39 de la Ley 17/1985, de la Función Pública de la Generalidad de Cataluña, modificada por la Ley 9/1994). Sin embargo, en el ámbito estatal se mantiene la definición de oposición acuñada en su Reglamento de 1968 (art. 2.2), y tan sólo se ha añadido la palabra capacidad, pero con una curiosa diferencia de orden en el Reglamento de 1984 ( «la oposición consiste en la celebración de una o más pruebas de 
capacidad para determinar la aptitud de los aspirantes" art. -3.2-) respecto del vigente RGIPP de 1995 ( "la oposición consiste en la celebración de una o más pruebas para determinar la capacidad y la aptitud de los aspirantes" - art. 4.2-), de tal manera que ahora parece romperse la identificación entre capacidad y aptitud, sin que alcancemos a comprender las posibles repercusiones de este cambio, salvo que se interpreten en la línea de la idoneidad (de la que capacidad y aptitud serían componentes).

Creemos que hoy en día no es posible defender que la fórmula históricamente acuñada en la expresión "mérito y capacidad" responda a una dualidad objetiva, sino que ha sido una formulación que ha permitido avanzar en la instauración de un sistema de mérito, que hoy se encuentra resquebrajado y que el cemento más consistente para ayudarnos a taponar esas grietas es reconducir esta fórmula al concepto idoneidad, con lo que el sistema de mérito podrá recomponer su legitimidad social originaria y recuperar su maltrecha credibilidad interna. Hay dos ejemplos jurisprudenciales suficientemente ilustrativos de la falsa dicotomía entre mérito y capacidad (o entre concurso y oposición, que es una falsa contraposición que, como ya hemos dicho, ha servido para ocultar el verdadero debate de fondo sobre el perfil o la idoneidad de los candidatos): la calificación de la cualidad de "jurista de reconocida competencia" y la exigencia y valoración de las lenguas autonómicas. En ambos casos el Tribunal Constitucional acaba pronunciándose por la postura "dual o bifronte» de esos requisitos de acceso a la función pública, de tal manera que a la vez constituyen una capacidad y un mérito. Veamos los razonamientos del Tribunal. En cuanto a la cualidad de «juristas de reconocida competencia» como uno de los requisitos exigidos para acceder a la función judicial por el denominado cuarto turno (art. 313 de la Ley Orgánica del Poder Judicial), el Tribunal Constitucional (STC de 23 de mayo de 1992) afirma que, por un lado, es un requisito de capacidad, de tal manera que si el aspirante no acredita tal cualidad no puede ser admitido al proceso de selección, pero, por otro lado, también «entraña un contenido de mérito, pues expresa un componente de conocimiento y de experiencia técnico-jurídica y alude a un claro contenido de valores ético-sociales y de prestigio", que deben ser valorados por el órgano de selección.

En el caso de la exigencia y valoración del conocimiento de las lenguas autonómicas en el acceso al empleo público el Tribunal Constitucional revisa su concepción original de calificar ese conocimiento como un mérito y le reconoce también la condición de requisito de capacidad:

"Sin embargo, el inciso impugnado del art. 34 de la Ley catalana 17/1985, al establecer la exigencia de conocimiento del cata- 
lán, parte de lo dispuesto en el inciso precedente, en el que se recogen los principios constitucionales de mérito y capacidad para el acceso a la función pública (art. 103.3 CE). Y dentro de estos principios es donde se sitúa el requisito de conocimiento del catalán. No resulta aceptable el argumento del abogado del Estado de que esa exigencia puede suponer un obstáculo para acceder a la función pública para quien carezca del conocimiento del catalán. El propio principio de mérito y capacidad supone la carga para quien quiera acceder a una determinada función pública de acreditar las capacidades, conocimientos e idoneidad exigibles para la función a la que aspira. Por lo que la exigencia del conocimiento del idioma que es oficial en el territorio donde actúa la Administración a la que se aspira a servir es perfectamente incluible dentro de los méritos y capacidades requeridas. No debe entenderse la exigencia de conocimiento del catalán un requisito ad extra, independiente del mérito y la capacidad acreditados, sino, al igual que cualquier otro conocimiento o condición exigida para el acceso a la función pública, una exigencia con cuya acreditación se da satisfacción a dichos principios constitucionales, en la medida en que se trata de una capacidad y un mérito que, según el art. 34 de la Ley catalana 17/1985, ha de acreditarse y valorarse en relación con la función a desempeñar y, por tanto, guarda la debida relación con el mérito y la capacidad, tal y como impone el art. 103 CE (STC 27/1991, fundamento jurídico $4^{\circ}$ )》 (FJ $3^{\circ}$ ).

Pero, además, el Tribunal Constitucional añade un nuevo argumento técnico: el principio de eficacia de las Administraciones Públicas, lo cual refuerza la idea de que la capacidad y el mérito deben valorarse en relación con las funciones que deberá desempeñar el candidato más idóneo. Veamos este razonamiento:

"En primer lugar, debemos mencionar el carácter del catalán como lengua de la Administración de la Generalidad, junto con el castellano, ambas de uso preceptivo (art. 5 Ley catalana 7/1983); que son válidas y eficaces las actuaciones administrativas bechas en catalán (art. 7.1 Ley catalana 7/1983); y que los particulares gozan del derecho de usar el catalán en sus relaciones con la Administración (art. 8 Ley catalana 7/1983 y STC $82 / 1986$, fundamento juridico $3 \%$. Además, se trata de un requisito justificado y equitativo también en función de la propia eficacia de la Administración autonómica (art. 103.1 CE), por lo que resulta constitucionalmente lícito exigir, en todo caso, un cierto nivel de conocimiento de la lengua catalana, que resulta 
imprescindible para que el funcionario pueda ejercer adecuadamente su trabajo en la Administración autonómica, dado el carácter cooficial del idioma catalán en Cataluña (art. 3. 2 CE y art. 3.2 EAC) y dada la extensión del uso del catalán en todo el territorio de la Comunidad Autónoma» (FJ $3^{\circ}$ ).

El reconocimiento jurisprudencial de la doble naturaleza de exigencia del conocimiento de una lengua autonómica nos sirve para plantearnos el siguiente interrogante: ¿cuál es el criterio sustantivo para decidir en cada caso si estamos ante un requisito de capacidad o ante un mérito? La primera respuesta es instintiva: según su valoración para el desempeño del puesto o el acceso al Cuerpo. Así, si consideramos que es un conocimientc imprescindible para el desempeño hablaremos de requisito de capacidad, mientras que si lo consideramos como un conocimiento no esencial podemos valorarlo como mérito. La conclusión inicial es que la gradación de su exigibilidad es el criterio determinante. Sin embargo, esta conclusión resulta inoperante cuando recordamos que el Tribunal Constitucional considera legítimo que el conocimiento de la lengua autonómica sea exigible con carácter general para el acceso a cualquier puesto o el ingreso en cualquier Cuerpo, con independencia del sistema de selección, como se desprende del art. 34 de la Ley de la Función Pública de la Administración de la Generalidad de Cataluña.

Esta constatación nos pone ante un hecho evidente e históricamente no cuestionado: cualquier clase de conocimiento tiene esa doble naturaleza, y se valora como requisito de capacidad o como mérito en función de su nivel de exigibilidad y, en su caso, según el sistema de comprobación (realización de exámenes o admisión de títulos). Es más, ese conocimiento puede ser condición previa de acceso, por ejemplo, cuando se exige una determinada titulación académica en función del grupo al que se pretende acceder, como establece el art. 25 de la Ley 30/1984 con carácter básico, y puede ser, al mismo tiempo, requisito de capacidad específica que se demuestra mediante la superación de las correspondientes pruebas. Pues bien, la cooficialidad de las lenguas autonómicas ha puesto en evidencia que lo importante es acreditar que se tienen conocimientos, siendo indiferente si se hace superando exámenes o aportando títulos, y así se viene admitiendo en las diferentes convocatorias.

Del análisis de estos supuestos podemos extraer las dos premisas necesarias sobre las que asentar una propuesta alternativa razonable, que nos pueda servir de orientación para reconducir la situación actual. Este análisis nos conduce al interrogante; ¿cuál debe ser hoy en día el contenido sustantivo del binomio «mérito y capacidad»? Podemos considerar perfectamente aplicable la respuesta dada por la reforma Carter en 1978: la valoración de los conocimientos, aptitudes y habilidades (KSA) para la selección de los candidatos idóneos. Ello tiene como 
consecuencia, en el caso español, la ruptura de los dogmas históricos por los que la oposición debe ser el sistema de selección predominante de funcionarios, o que en ella deben primar los conocimientos, o por el cual el concurso es mejor para seleccionar personal laboral. De esta manera el debate sobre los instrumentos de selección queda reducido a su verdadera dimensión: ¿ por qué es mejor utilizar un sistema que otro? Y ello nos lleva a la discusión sobre adecuación de cada sistema para valorar los conocimientos, aptitudes y habilidades. Consecuentemente, la discusión se reconduce a los contenidos a valorar: la clase de conocimiento (académicos o profesionales, teóricos o prácticos, de cultura general o especializada, jurídicos o no jurídicos, etc.), su cuantía (si son suficientes para desempeñar el puesto o ejercer la función, o deben ser complementados con una formación adicional en el proceso de selección); las aptitudes imprescindibles (capacidad de mando, aptitud para tratar con el público, capacidad de resistencia a las presiones, aptitud para trabajar en equipo, etc.); las habilidades predominantes (de carácter directivo, para gestionar conflictos, para conseguir resultados, etc.). En esta lógica, primero tenemos que definir el perfil del candidato y luego optamos por el instrumento de selección más adecuado para medir los contenidos que nos interesan, y no debemos dudar en cambiar de sistema una vez comprobado que no da los resultados esperados. En el sector privado está arraigando la idea de que lo que se debe valorar son "competencias" (FERNANDEZ, G.: 1996), que vendrían a ser un desarrollo de la formulación acuñada por la reforma Carter. Pero, paradójicamente, las organizaciones empresariales y los sindicatos han decidido utilizar la expresión "mérito y capacidad» acuñada en el sector público (art. 10.3 del Acuerdo sobre Cobertura de Vacios integrantes del denominado Pacto Laboral firmado el 28 de abril de 1997).

De este modo queda claro que la discusión importante es la relativa al perfil del candidato, quedando relegado a un segundo plano la relativa al sistema de selección. En este contexto se hace imprescindible una rigurosa regulación de técnicas de selección como la entrevista o los tests psicotécnicos. Por ello, la clarificación sobre el contenido que se quiere valorar y la objetividad y adecuación del sistema de selección se convierten en las mejores garantías del derecho fundamental de igualdad en el acceso, permitiendo de este modo un avance cualitativo imprescindible en el desarrollo y aplicación real de la fórmula histórica recogida en la Constitución de 1978.

\section{B) Principio de mérito y carrera administrativa}

El establecimiento de una verdadera carrera administrativa es, paradójicamente en un sistema tradicionalmente considerado de "carrera", 
la gran asignatura pendiente de las diferentes reformas habidas en este siglo, pues cuando el diseño teórico parecía sentarse sobre unas bases coherentes, la realidad cotidiana lo acababa transformando en irreconocible (el caso del Estatuto de Maura de 1918 y el deterioro del sistema de categorías) y cuando se busca alternativas en otros modelos (la idea de puesto) el sistema no acaba de asimilarlos y lo excepcional se convierte en normal (el abuso de la libre designación en las reformas de 1964 y de 1984). El legislador de 1984, haciéndose eco de una demanda unánime de partidos políticos y sindicatos, no dudaba en proclamar que se afronta «de una manera realista, el problema de la carrera administrativa" $y$ afirma que "una auténtica carrera administrativa " debe basarse en la clasificación de puestos (Exposición de Motivos de la Ley 30/1984). Pero ya tempranamente la doctrina advirtió de las deficiencias técnicas de la nueva reforma (GUTIÉRREZ REÑON: 1987), y a finales de los ochenta los responsables ministeriales elaboraban un duro diagnóstico en un documento titulado "Reflexiones para la modernización de la Administración Pública", en el que la parte principal de sus propuestas estaban orientadas a articular la prometida carrera administrativa; sin embargo, como ya apuntamos anteriormente, a la hora de plasmar las propuestas parecía que los redactores del BOE iban por libre y daban a luz a normas contradictorias con esos nuevos postulados teóricos. El balance actual es bastante desolador, como pone de relieve ARROYO YANES, en el estudio más exhaustivo que hasta ahora se ha hecho sobre la carrera administrativa de los funcionarios públicos, pues finaliza su análisis afirmando que «la conclusión final a que lleva cuanto antecede no es otra que la inexistencia en nuestro ordenamiento de una carrera profesional propiamente dicha, pues a pesar de que el legislador ha intentado bosquejar una serie de instrumentos normativos que posibiliten la articulación de carreras individuales, éstas encuentran en su desarrollo un gran número de obstáculos derivados de un tratamiento legal defectuoso, que pone en entredicho la autenticidad del deseo del legislador de fomentar semejante instituto jurídico $y$ de convertirlo en uno de los pilares fundamentales de la estructuración de nuestra función pública de finales del siglo XX» $(1994,551)$. Este negativo balance se explica por el fracaso del legislador para articular coherentemente las relaciones entre el grado personal, el puesto y el cuerpo. Conviene recordar que este fracaso es un importante lastre para el adecuado funcionamiento de las instituciones del Estado democrático, pues, en palabras de GUTIERREZ REÑON $(1987,62)$, «la organización de la carrera administrativa tiene como objetivo fundamental proporcionar a la Administración las personas con la capacidad necesaria para asegurar la gestión eficaz de los intereses públicos».

En esta misma línea, de dotar a la Administración de los profesionales adecuados, podemos plantear la importancia del principio de 
mérito en esa profesionalización, con independencia de que hablemos de un sistema de carrera o de un sistema de puestos, o de un híbrido, como es nuestra situación actual. Pues bien, la primera pregunta que surge es ¿los principios de mérito y capacidad son aplicables con la misma intensidad en el desarrollo de la carrera que en la fase de acceso? Dicho en otras palabras, ¿hasta qué punto el mérito y la capacidad son los únicos criterios en la decisión de proveer puestos de funcionarios? La respuesta es clave para concretar el alcance del derecho fundamental de igualdad en el acceso a los cargos y funciones públicas y para enmarcar los límites de la carrera de funcionarios. Podemos afirmar que hasta finales del año 1991 el Tribunal Constitucional mantenía que el mérito y la capacidad eran los únicos criterios utilizables tanto en la fase de acceso como en la de provisión de puestos, y así lo expresa:

"Con reiteración hemos puesto de relieve, en efecto, la relación recíproca que discurre entre el derecho a la igualdad en el acceso a las funciones y cargos públicos, consagrado en el articulo 23.2 de la Constitución, y los principios de mérito y capacidad que deben regir dicho acceso según el articulo 103.3 del mismo texto constitucional (Sentencias 75/1983, 50/1986, 148/1986 y 193/1987, entre otras). Con arreglo a este último precepto, $y$ teniendo en cuenta el principio de igualdad, la resolución de un concurso para cubrir una plaza de funcionario ha de bacerse de acuerdo con un criterio estrictamente técnico, valorando exclusivamente el mérito y la capacidad de los aspirantes" (STC 215/1991, FJ $3^{\circ}$ ).

Sin embargo, esta "reiterada doctrina" se ha resquebrajado en dos sentencias del mes de octubre del mismo año 1991: la Sentencia 192/1991, de 14 de octubre y la Sentencia 200/1991, de 28 de octubre. En estas dos sentencias referidas al mismo tema (la constitucionalidad del denominado turno o derecho de consorte) se establece una innovación que rompe la doctrina sobre la utilización exclusiva del mérito y la capacidad como criterios de adjudicación de plazas tanto para el ingreso inicial como en el desarrollo de la carrera mediante las diferentes formas de provisión de puestos. Se establece una distinción entre el papel del mérito y la capacidad en la fase de ingreso y en la fase ulterior de provisión de vacantes:

«4. Enmarcado el problema en el ámbito del art. 23.2 de la CE, ningún reparo cabe oponer a la proyección del principio de igualdad no sólo en el momento del acceso a las funciones públicas, sino también a todo lo largo de la duración de la relación fun- 
cionarial o asimilada a estos efectos [entre otras, SSTC 15/1988, fundamento jurídico $2^{\circ}$ (con remisión a la STC 75/1983) y $47 / 1989$, fundamento jurídico $2^{\circ} \mathrm{J}$, siendo aplicable, por tanto, a los actos posteriores al acceso y, entre ellos, a los relativos a la propia provisión de puestos de trabajo. Sin embargo, tampoco debe ignorarse la distinta consideración que, a estos efectos, merecen, de una parte, el acceso a la función pública y, de otra -dentro ya de la misma- el desarrollo o promoción de la propia carrera administrativa, $y$, por consiguiente, el diferente rigor e intensidad con que en cada una de ellas operan los derechos y valores constitucionales como son el acceso en condiciones de igualdad (art. 23.2 CE) y de acuerdo con los principios de mérito y capacidad (art. 103.3 CE:) a las funciones públicas. Pues, en efecto, siendo el derecho del artículo $23.2 \mathrm{CE}$ un derecho de configuración legal, puede la Administración legitimamente dentro de los concursos para la provisión de vacantes o puestos de trabajo entre personas que ya han accedido a la función pública $(y$, por tanto, acreditado los requisitos de mérito y capacidad) tener en cuenta otros criterios distintos que no guarden relación con éstos, en atención, precisamente, a una mayor eficacia en la organización de los servicios o a la protección de otros bienes constitucionales. Tal es el caso aqui contemplado del denominado derecho de consorte que, dada la forma en que normativamente ha sido previsto, no puede estimarse que sea contrario al art. 23.2 CE - ni por tanto al articulo $14 \mathrm{CE}$ - ni menos aún que discrimine a la recurrente, que ni siquiera habia concursado a la plaza».

Veamos como desarrolla esta argumentación el Tribunal Constitucional. En primer lugar, habla de «la protección de otros bienes constitucionales" a tener en cuenta por la Administración en la regulación de la provisión de puestos y hace referencia, en este caso, a la familia, cuya protección debe ser asegurada por los Poderes Públicos en cumplimiento del art. 39.1 de la Constitución, a lo que se contribuye «eliminando trabas para el cumplimiento del deber de convivencia a que se refiere el art. 68 del Código Civil». Pero esta argumentación, que admite el trato desigual por razón del estado civil (los solteros no pueden beneficiarse del derecho de consorte) amparándose en la protección de la familia (STC 192/1991), resulta desvirtuada por el mismo Tribunal Constitucional cuando en una sentencia inmediatamente posterior (STC 200/1991) utiliza el mismo razonamiento legitimando el distinto trato entre funcionarios casados, de manera que el derecho de consorte se limita en su ejercicio a los funcionarios cuyo cónyuge también es funcionario, con lo que se está admitiendo que los Poderes Públicos actúen discriminatoriamente: en este caso protegiendo sólo a 
las familias formadas por ambos cónyuges funcionarios, olvidando que los otros funcionarios casados con no funcionarios también tienen que cumplir el deber de convivencia. Pero para el TC ésta no deja de ser una "aparente» contradicción que se resuelve expeditivamente: el trato diferente se justifica porque son situaciones diferentes, de aquí la «razonabilidad» de la diferenciación.

En segundo lugar, justifica la utilización de criterios ajenos al mérito y a la capacidad por razones de «mayor eficacia en la organización de los servicios", pues la eficacia es un principio constitucionalmente amparado (art. 103.1), «lo que legitima la adopción de aquellas medidas que tiendan precisamente a que el personal al servicio de las Administraciones Públicas se encuentre en las mejores condiciones para el desarrollo de la actividad profesional de su cargo". Este razonamiento entra en contradicción con el de admitir un tratamiento diferenciado entre funcionarios casados con funcionarios y los casados con no funcionarios, pues resulta que sólo se está cumpliendo el mandato de eficacia en relación con el primer grupo de funcionarios. Por tanto, el principio de congruencia exige que el TC resuelva esta contradicción legitimadora de las dos variantes de ejercicio del derecho de consorte.

Adentrándonos ahora en lo que creemos es el punto neurálgico que afecta a la configuración constitucional de la relación entre los artículos 23.2 y 103.3, analicemos la doble argumentación esgrimida por el Tribunal Constitucional para fundamentar la exigencia de "diferente rigor e intensidad" con que ambos preceptos operan en el ingreso y en la provisión de puestos, componentes de lo que el mismo TC ha subsumido en el derecho de acceso. Como primera justificación el TC nos dice que las personas que ya han accedido a la función pública tienen acreditados los requisitos de mérito y capacidad; pero se olvida de que entre los candidatos que compiten por acceder a otra vacante debe seguir respetándose el derecho de igualdad, cuyos parámetros de constitucionalidad siguen siendo el mérito y la capacidad, salvo que una norma con rango de ley establezca un trato desigual amparándose en la protección de la igualdad real del art. 9.2 $\mathrm{CE}$ (recordemos que las dos normas analizadas por el TC tienen rango reglamentario: un Decreto del año 1935 y una Orden de 1986). En segundo lugar, el TC se intenta cobijar en la naturaleza de derecho de configuración legal con que él mismo ha caracterizado al art. 23.2 CE; pero se olvida de que previamente ya había establecido una reiterada doctrina sobre el contenido y las consecuencias de dicha calificación, entre las cuales está el hecho de la obligatoriedad de la fundamentación objetiva de cualquier requisito, lo que implica que debe estar referido a criterios de mérito y capacidad. Y en aplicación de esa doctrina, el Tribunal Supremo declaró en el año 1986 (STS de 11 de julio, Ar. 4.349) la nulidad del Reglamento General de Provisión de Puestos de Trabajo y de 
Promoción Profesional de los Funcionarios de la Administración Civil del Estado del año 1985, porque introducía una limitación no prevista en la Ley 30/1984, de 2 de agosto, de Medidas para la Reforma de la Función Pública. Pues bien, el Tribunal Constitucional se desentiende de esta actuación del Tribunal Supremo sin mayores profundidades: en el primer caso, de la regulación del derecho de consorte por la Orden de 1986, se limita a ignorar la sentencia del Tribunal Supremo, a la que no hace mención alguna; y en el segundo, dice que tanto la Resolución impugnada como el Decreto regulador son anteriores al Reglamento General de Provisión de Puestos, y por tanto no era de aplicación. Preocupante actitud la de tener que escudarse en argumentos formales y no intentar rebatir con argumentos de fondo la aplicación de su propia doctrina por el Tribunal Supremo.

Por último, recordemos que en relación con el "desarrollo o promoción de la propia carrera administrativa" el Tribunal Constitucional fue contundente en su Sentencia 99/1987, de 11 de junio, al afirmar que los requisitos objetivos para la adquisición de grados personales como forma de promoción «deben fundarse exclusivamente en criterios de mérito y capacidad, evitando toda discriminación»; $y$ así lo ha recogido el legislador estatal (Arts. 20.1 a y 22.1 de la Ley 23/1988).

JIMÉNEZ ASENSIO también ha criticado duramente esta doctrina que el Tribunal reitera en sus sentencias 293 y 365 del año 1993, especialmente por su amparo en el principio de eficacia y el impacto que puede tener en la provisión de puestos funcionariales directivos:

"Segín este razonamiento, que sigue anclado en el esquema anterior, resulta paradójico, sin duda, que se recurra al principio de eficacia precisamente para justificar que los principios de mérito y capacidad deban ceder ante otros criterios en la provisión de puestos en la Administración pública. Si se extiende esta doctrina a la provisión de puestos directivos, ello implica que seria más eficaz desde el punto de vista organizativo un nombramiento que prescindiera de evaluar la capacidad de la persona designada. El argumento utilizado es, por tanto, criticable, pues no hay nada mejor para garantizar la eficacia de la Administración pública que proveer puestos directivos con personas que tengan capacidad y méritos contrastados.

Además, la doctrina sentada en la STC 293/1993 llega hasta tal punto que justifica la discrecionalidad en la provisión de puestos $(y$, por tanto, el apartamiento de los principios de mérito $y$ capacidad) basándose en que el "perfil profesional de algunos puestos de trabajo requiere ciertas cualidades subjetivas, conocimientos o una especial dedicación que pueden ser valorados en 
la selección del candidato idóneo para desempeñarlos» (fi. S). ¿Qué es eso sino la capacidad?; ¿qué otro medio hay de comprobar que una persona ostenta cualidades especificas para el desarrollo de un puesto, conocimiento o experiencia, sino a través de un proceso selectivo público y objetivo?» $(1996,59)$.

A modo de conclusión, podemos decir que en la nueva configuración constitucional el mérito y la capacidad son los parámetros de constitucionalidad en la regulación y aplicación del derecho fundamental de acceso en igualdad de condiciones, sin que sea admisible rebajar su rigor o intensidad en el desarrollo de la carrera administrativa o profesional utilizando criterios ajenos a estos parámetros, salvo que tengan su fundamentación en la igualdad real del art. 9.2 CE. En definitiva, y parafraseando al TC, el mérito y la capacidad deben ser la regla para la adjudicación de puestos y funciones. El problema de fondo sigue siendo la delimitación de para qué puestos y funciones dejan de ser estos principios los exclusivos, ya sea porque se incorporan otros criterios (el de confianza en la libre designación), o porque son totalmente sustituidos por otros (puestos reservados a personal eventual).

El otro tema condicionado por la respuesta resultante de la aplicación del principio de mérito es el de los límites de la carrera profesional. Aquí la discusión acostumbra a centrarse en la utilización de los dos métodos de provisión clásicos: el concurso de méritos y la libre designación. En sentido estricto, la carrera por el mérito tiene su techo en los puestos que puedan cubrirse mediante concurso que, recordémoslo, desde el año 1964 se establece como el sistema normal, aunque su arrinconamiento tanto en la etapa pre como postconstitucional obligó a los Tribunales de Justicia a exigir su respeto ante el abusivo uso del sistema de libre designación, donde el criterio predominante es la confianza. La delimitación de qué puestos deben cubrirse mediante libre designación plantea el problema de la relación entre lo que JIMÉNEZ ASENSIO denomina "función pública directiva" (1996, 189 a 191) y su articulación con el sistema de carrera. Y como señala el mismo autor, en nuestro país sigue siendo un tema pendiente, pues la libre designación actúa como una especie de spoil system de circuito cerrado y, por otro lado, la credibilidad del sistema de concurso, concretamente en su modalidad de concurso específico, está bajo mínimos (ARROYO YANES: 1994, 545). Por tanto, la resolución de los límites de la carrera basada en el mérito pasa por delimitar el ámbito de una verdadera función directiva profesionalizada, que, como apunta JiMÉNEZ AsENSIO (1996, 285 a 290), debería contar con un Estatuto jurídico propio y distinto del Estatuto de la Función Pública. 


\section{C) Derecho al cargo, inamovilidad y situaciones administrativas}

Estos son tres conceptos tradicionales que han servido para vertebrar nuestro sistema de función pública, pero creemos que hoy en día necesitan una revisión en profundidad. La doctrina ha establecido una estrecha conexión entre estos tres conceptos: se acostumbra a identificar derecho al cargo e inamovilidad (PARADA: 1996, 465; ENTRENA: 1995, 293 y 294), pudiendo ésta referirse a la inamovilidad funcional, geográfica, o relacional (no separación del servicio si no es por causas disciplinarias). Para garantizar la inamovilidad se articula un sistema de situaciones administrativas, entre las que sobresalen la situación de servicio activo (que debe ser la normal y garantiza el pleno ejercicio del derecho al cargo) y la de excedencia forzosa (que garantiza el mantenimiento de la relación de servicio aun cuando no se está desempeñando función alguna). Estos tres conceptos técnicos se han legitimado históricamente por su vinculación con el principio de imparcialidad, exigencia ineludible de una Administración profesionalizada estructurada en un sistema de mérito. $\mathrm{Y}$ jurídicamente se cimentaba su conexión en la distinción entre relación orgánica y relación de servicio (GARCla-TreviJANo Fos: 1970, 466 a 479), pero ésta es una formulación que, aunque ha cumplido una importante función histórica, hoy en día es difícilmente sostenible (SANTAMARÍ PASTOR: 1984, 59 a 61), pues la única relación jurídica es la relación de servicio entre el funcionario como persona física y la Administración como persona jurídica. La utilidad de esa distinción se concretaba en el sistema de situaciones administrativas, que permiten suspender temporalmente la relación orgánica, es decir, el desempeño de un puesto en un órgano concreto, mientras permanece la relación de servicio con la Administración sin que se rompa el vínculo jurídico que se inició con el nombramiento como funcionario. Sin embargo, hoy en día, este planteamiento tiene plena vigencia en el sector privado, pues recordamos que el vigente Estatuto de los Trabajadores permite suspender el contrato de trabajo utilizando, entre otras, la excedencia voluntaria (en algunos casos plenamente coincidente con la del funcionario público) o la excedencia forzosa (que conlleva reserva de puesto y cómputo de antigüedad, al igual que en la situación de servicios especiales para los funcionarios), cuya regulación reproduce, curiosamente, casi literalmente el Estatuto de Maura de 1918.

La revisión de estos conceptos debe mantener la referencia al principio de imparcialidad, pero debe hacerse en la búsqueda del equilibrio, una vez más, entre el interés de la organización (concretado en el uso de una potestad de organización) y el derecho del funcionario al desempeño de unas funciones, con independencia del 
puesto orgánico en que lo realice (movilidad funcional) y sin que la movilidad geográfica sea un límite que pueda conducir a la situación de excedencia forzosa (como sucede con los actuales procesos de reasignación). Un nuevo modelo de recursos humanos basado en los conceptos de flexibilidad y polivalencia deberá ampararse en un ejercicio de los potestades organizativas formulado de manera objetiva y transparente y controlable jurídicamente, siendo esencialmente coincidente con la lógica del sector privado, como ya comprobamos en el apartado anterior. En este sentido, nos parece poco realista algún planteamiento doctrinal que apunta una rigidificación del derecho al cargo, pretendiendo reconstruir una teorización del régimen de la función pública a partir de este concepto y revistiéndolo de una irreal armadura forjada de un hipotético garantismo que deberá evitar el "desmoronamiento de todo orden racional y objetivo del régimen funcionarial que trae consigo la ineficacia de la Administración» (MARTÍNEZ DE PISÓN: 1995, 107). Creemos que lo sensato es, huyendo de catastrofismos, debatir el papel del actual sistema de situaciones administrativas, que debe ser profundamente revisado, y establecer los límites y garantías de la inamovilidad, incluida la inamovilidad relacional, cuya garantía última, la excedencia forzosa, se ha configurado como una situación de desempleo indefinido (cuando un empleado de la misma Administración Públi$\mathrm{ca}$, realizando las mismas funciones pero en régimen de Derecho Laboral tiene predeterminada la caducidad de su desempleo). No parece razonable que, mientras existe la posibilidad de recolocar a un funcionario cuyo puesto ha sido suprimido, la movilidad geográfica más allá del ámbito provincial sea insalvable ante la negativa del funcionario a cambiar de residencia y esta negativa se premie con una situación de paro ilimitado; las Administraciones han de agotar todas las posibilidades de recolocación, incluso mediante con convenios con otras Administraciones, pero el funcionario debe demostrar que realmente tiene voluntad de continuar prestando servicios en el sector público en las mismas condiciones que lo haría en el sector privado en una situación similar.

\section{D) Sobre la necesaria reconducción del estéril debate entre funcionarios y laborales como una discusión sobre regimenes jurídicos}

Pocos temas han hecho correr tantos ríos de tinta y de forma tan estéril en los últimos tiempos como el debate sobre la dualidad de regímenes jurídicos en el empleo público. Y lo calificamos de estéril por las siguientes razones: 
1) Es un debate descontextualizado, olvidando que el verdadero tema de fondo es su diferente fundamento institucional (PRATS) y su adecuación a cada modelo organizativo, cuyo diseño predetermina el modelo de personal, pues reducir la discusión al simple cambio de marco jurídico es caer en una «visión totémica» de dicha reforma legal (LoNGo: 1995a, 5) y magnificar el Estatuto de la Función Pública como principal instrumento del sistema de gestión pública de los recursos humanos, cuando su función es otra: clarificar las reglas del juego y garantizar determinados valores constitucionales.

$\left.2^{a}\right)$ Es una polémica maniquea, en la que los contendientes no admiten ninguna razón de su oponente. Así, los defensores de la existencia de un solo régimen, el funcionarial, mantienen la inconstitucionalidad de la dualidad de regímenes (a pesar de la reiterada doctrina del Tribunal Constitucional admitiendo el personal al servicio de las Administraciones en régimen laboral) y descalifican lo que llaman «laboralización» del sistema de carrera "porque es la negación misma del sistema de función pública» (PARADA: 1996, 430) y porque "la flexibilidad del Derecho Laboral basada en la discrecionalidad del empresario, en este caso la Administración, va en detrimento de la profesionalidad del empleado público, de su imparcialidad, neutralidad y objetividad, valores que justifican la aparición del modelo funcionarial, no parece que quede un solo argumento en pie para justificar las ventajas de la contratación laboral frente a la relación funcionarial en el seno de la Administración Pública» (DEL SAZ: 1995, 94). Por contra, los defensores radicales de la extensión del régimen laboral a todos los empleados públicos entienden que es la única manera de superar un modelo rígido y anacrónico, que se ha acabado convirtiendo en un auténtico lastre para la sociedad y que es incapaz de adaptarse a los vertiginosos cambios de entorno que acontecen; por ello, propugnan que se tomen como referencia los valores y principios de la empresa privada, especialmente en todo lo que suponga eliminar rigideces y avanzar en la supresión de lo que entienden son privilegios (la inamovilidad).

$3^{\text {a) }}$ Los constantes cambios de orientación y contradicciones del legislador han creado un auténtico laberinto jurídico ante el que muy pocos autores se han atrevido a realizar propuestas concretas y viables (SANCHEZ MORON, MONTORO CHINER), partiendo de la innegable realidad de que casi el cincuenta por ciento de los empleados públicos son personal laboral.

$\left.4^{a}\right) \mathrm{Ni}$ el legislador ni la doctrina han sido capaces de establecer un fundamento objetivo que explique la separación de ambos regímenes. Así, el mismo legislador y en la misma norma (Ley 23/1988) utiliza, por un lado, un criterio funcional, cuya concreción ha sido duramente criticada por la doctrina por no existir racionalidad alguna entre los supuestos laboralizadores que contempla (art. 
15.1c) y, por otro lado, acude a un criterio organizativo, según el cual el personal de los Entes Públicos deberá ser laboral (Disposición adicional decimoséptima). La no articulación de ambos criterios, que nos parece la clave para defender la idoneidad de uno u otro personal, se pone de manifiesto cuando Entes Públicos que ejercen "potestades públicas" cuentan con un personal sujeto al régimen laboral (Comisión Nacional del Mercado de Valores, Agencia de Protección de Datos, etc.), o se añade un nuevo supuesto de laboralización (Ley 42/1994) que, interpretado en sentido amplio, puede explicarse como «una cláusula de cierre en la que tienen cabida todos aquellos puestos que no implican ejercicio de autoridad o de prerrogativas públicas» (DEL SAZ: 1995, 53), lo que puede conducir a laboralizar puestos que venían siendo desempeñados por funcionarios, creando de nuevo más agravios comparativos entre personas que realizan las mismas funciones con diferentes regímenes. La explicación de este nuevo supuesto laboralizador la hemos de buscar en el Acuerdo Sindicatos-Administración para el bienio 1995-1997 (apartado 3 del capítulo XXXIII) que, al mismo tiempo, potencia los procesos de funcionarización (capítulo XXIV). Por otro lado, doctrinalmente podemos partir de la sólida reflexión de PRATS abordando la necesaria distinción entre empleo público y función pública, en este mismo número.

Ante este panorama de confusión nos parece que el debate debe reconducirse partiendo de un diagnóstico riguroso de las deficiencias del actual modelo de gestión de recursos humanos, analizando su articulación con las diferentes alternativas organizativas y elaborando propuestas orientadas a lograr un equilibrio entre los principios constitucionales de eficacia, objetividad e imparcialidad. En esta línea nos parece útil el análisis de la singularidades del empleo público, más allá del coyuntural régimen jurídico que deberá ampararlas, pues en la medida en que las mismas estén fundamentadas habremos dado un paso importante para recomponer su credibilidad institucional y contribuir a que la sociedad perciba que cuenta con una Administración altamente profesionalizada y preparada para afrontar los retos del nuevo siglo.

\section{BIBLIOGRAFÍA}

ALARCÓN CARACUEL, Manuel Ramón: La nueva configuración legal de la relación de empleo público: funcionarios y contratadores laborales. Instituto de Estudios de Administración local. 1985.

Alegre Ávila, José Manuel: “Objetividad e imparcialidad de la Administración. El principio de especialidad en la composición de los órganos de selección", en Homenaje al Profesor González Pérez, Civitas, 1993. 
«La función pública y los interinos y contratos (La Sentencia del Tribunal Constitucional 67/1989, de 18 de abril. Una reflexión sobre los principios constitucional de igualdad, mérito y capacidad)». REALA, 243, 1989.

ALdoma BuIXadé, Josep: Les relacions de Llocs de Treball de les Administracions Públiques, CEDECS, 1996.

«Plans d'ocupació i relacions de llocs de treball als ens locals" en Planificació: gestió de l'ocupació als ens locals, CEMICAL, Barcelona, 1996.

Alonso Olea, Manuel y CASAS BAAMONDE, $M^{a}$ Emilia: Derecho del Trabajo, Universidad Complutense de Madrid, 1995.

ÁlVAREZ ÁlvAREZ, Julián: «Neutralidad política y carrera administrativa de los funcionarios públicos", $D A, 210-211,1987$.

ARROYO YANES, Luis Miguel: La carrera administrativa de los funcionarios públicos, Tirant lo Blanch, 1994.

El funcionario interino, Tecnos, 1996.

«El derecho funcionarial de consorte ante el Tribunal Constitucional (STC 200/91 de octubre)", RAP, 10, 1992.

BAENA DEL ALCAZAR, Mariano: Estructura de la función pública y burocracia en España, INAP, 1994.

BAÑo LEÓN, José María: «Garantía constitucional de la función pública y reforma adiministrativa", Cuadernos del Poder Judicial, 1995.

BEATO ESPEJO, Manuel: «La imparcialidad de los funcionarios públicos, dimanante del derecho al acceso con igualdad. Garantías jurídicas" en Jornadas del Ministerio de Justicia, 1992.

BERMEJO CABRERA, Fernando: «Las relaciones de puestos de trabajo y la laboralización de la Función Pública», REDA, 62, 1989.

BELTRAN DE FELIPE, Miguel: Discrecionalidad administrativa y Constitución, Tecnos, 1995.

BETANCOR RODRf́GUEZ, Andrés: Las Administraciones independientes, Tecnos, 1994.

CARrillo Barroso, Ernesto: Gestión de Recursos Humanos, Presupuestación y Hacienda Local en España, Instituto de Estudios Fiscales, 1991.

CASTILlo Blanco, Federico A.: Acceso a la función pública local (Políticas selectivas y control jurisdiccional), Comares, 1993.

"Las problemáticas fronteras entre el Derecho Laboral y el Derecho Administrativo: a propósito de los contratos temporales en el sector público", REDA, 86, 1995.

CRUZ Villalón, J.: «El art. 41 del Estatuto de los Trabajadores tras la reforma de 1994", RC, 17-18, 1994.

ECHEBARRIA, Koldo: «El cambio y la gestión del cambio en la Administración Pública (cambio planificado v. inercia administrativa)", en Modernización Administrativa, 1988.

La Administración Pública en la era del Management. Reflexiones sobre una época de modernización administrativa, 1993 (tesis doctoral Universidad de Deusto).

EMBD IRUJo, Antonio: «Trece proposiciones sobre selección de funcionarios y provisión de puestos de trabajo en el Derecho español", Administración de Andalucia. Revista Andaluza de Administración Pública, nº 13, 1993.

La fidelidad de los funcionarios a la Constitución (un estudio de los Derechos alemán y español), INAP, 1987. 
ENTRENA CUesta, Rafael: Curso de Derecho Administrativo. Organización Administrativa, 1/2, Tecnos, 1995

«El régimen estatutario de los funcionarios públicos como postulado constitucional» en Estudios sobre la Constitución (Homenaje a E. García de Enterría). Civitas, 1991.

Fabregat Romero, Pilar y URanga Cogollos, Carlos: «La selección de personal en la Administración Pública: el mito del Administrador educado", Revista Internacional de Ciencias Administrativas, 57-2, 1991.

FÉrEZ, Manuel: «La carrera administrativa en los Estados Unidos", $D A$, 210-211, 1987.

«La igualdad, el mérito y la capacidad de acceso al empleo público profesional (los casos de Estados Unidos, Francia y España)", 1993. (Tesis doctoral, Universidad Autónoma de Barcelona).

"Selección y promoción interna de los funcionarios locales", en Función Pública Local, Federació de Municipis de Catalunya, 1991.

FERNANDEZ, Guadalupe y otros: Las competencias: clave para una gestión integrada de los recursos humanos, Deusto, 1996.

FERNANDEZ FARRERES, Germán: «La potestad legal de autoorganización: contenido y límites", en Tratado de Derecho Municipal, Civitas, 1988.

"Estado del Bienestar, Administración y función pública» en Revista Aragonesa de Administración Pública, 3, 1993.

GARCIA DE ENTERRfA, Eduardo: Democracia, jueces y control de la Administración, Civitas, 1995.

La Administración española, Alianza Editorial, 1972.

GARCIA MURCIA, J.: «La incidencia de la Ley 11/1994 en la regulación de los traslados y desplazamientos de trabajadores", $R L, 17-18,1994$.

Garcia-Trevijano Fos, José Antonio: Tratado de Derecho Administrativo, Tomo III, vols. y 2, Revista de Derecho Privado, 1970.

GaRCí-TREVIJANo GaRnICA, Ernesto: «El turno de consorte y el derecho a la igualdad", $R E D T, 55,1992$.

GODINO REYES, Martín: El contrato de trabajo en la Administración Pública, Civitas, 1996.

GoODALES, James G.: La entrevista, traducido por Rafael Burgoleta y María Manuela Pérez, Pirámide, 1992.

GONZALEZ-HABA GUISADO, V.M.: "Los problemas del personal no funcionario", REALA, 225, 1985.

«Política de personal y riesgos estructurales de la función pública española", $R E V L, 220$.

«En torno a las oposiciones restringidas», REDA, 50, 1986.

GUTIÉRREZ REÑóN, Alberto: «La carrera administrativa en España: evolución histórica y perspectivas», DA, 210-211, 1987.

JIMÉNEZ ASENSIO, Rafael: Políticas de selección en la función pública española (1808-1978), MAP, 1989.

Altos cargos y Directivos Públicos, IVAP, 1996.

JiMÉNEZ ASENSIO, Rafael y MESA DEL OLMO, Adela: La libre designación en la función pública vasca, Robles-Arangiz Institute, 1993.

LEVY-LEBOYER, Claude: Evaluación del personal, Díaz Santos, 1992. 
LOPEZ GARRIDO, Diego: «El acceso a la función pública en la Europa de los doce", RVAP, 36. 1993.

LONGO, Francisco: "Reforma del empleo público: Totem y tabú», Revista Gestión y Análisis de Políticas Públicas, 2, 1995a.

«El debate sobre funcionarización y laboralización en las Administraciones Públicas", en Jornadas sobre Función Pública Local, Federació Valenciana de Municipis i Provincies, 1995b.

"Políticos, directivos y sindicatos como actos de la gestión de recursos humanos en las Administraciones Píblicas", Papers ESADE, 148, 1996.

LOPEZ BENTTEZ, Mariano: El contrato de trabajo en la Administración Pública, Civitas, 1996.

LOPEZ-FONT MARQUEZ, José Francisco: La configuración jurídica del principio de autoridad, Civitas, 1993.

MARTIN MATEO, Ramón: "La inamovilidad de los funcionarios públicos", RAP, 51, 1966.

MARTIN-ReTORTILLO BAQUER, Lorenzo: «Pervivencias del 'spoil system' en la España Actual", Anuario de Derecho Constitucional y Parlamentario, Asamblea Regional de Murcia-Universidad de Murcia, 1993.

MARTINEZ MARIN, Antonio: Una teoría sobre nuestra organización pública y sus principios, Tecnos, 1996.

MARTINEZ ABASCAL, U.A.: «Flexibilidad laboral y reforma de la normativa sobre movilidad funcional», Revista Española de Derecho del Trabajo, 67,1994 .

MARTINEZ DE PISÓN, Iñigo: «La potestad organizatoria y los derechos de los funcionarios públicos» en Estudios de Homenaje al profesor Jesús González Pérez, III, Civitas, 1993.

Régimen jurídico de la función pública y derecho al cargo, Civitas, 1995 a.

El ocaso de la función pública: la reforma del régimen jurídico funcionarial de la Ley 22/1993, de 29 de diciembre, Civitas, 1995 b.

Monereo Pérez, José Luis y VIDA SORIA, José: La condición de nacionalidad en el acceso del personal a los empleos públicos, MAP, 1991.

MONTORo CHINER, María Jesús: «Para la reforma del empleo público: nuevas proposiciones", RAP, 136, 1995.

MONTOYA MELGaR, Alfredo: Derecho del Trabajo, 1996.

El poder de dirección del empresario, 1965.

«Poder de dirección del empresario" Enciclopedia Jurídica Básica, III, 1995.

«La nueva configuración del poder de dirección del empresario» en Reforma de la Legislación laboral, $1995 \mathrm{~b}$.

Morell OCAÑA, Luis: Apuntes de Derecho Administrativo. Derecho de la organización administrativa, 1988. 1994.

El sistema de la confianza política en la Administración pública, Civitas,

«El principio de jerarquía en la Administración. Del paradigma de la objetivación al de la «fidelitas" personal», DA, 229, 1992.

"El principio de objetividad en la actuación de la Administración Pública» en Estudios de Homenaje al profesor Jesús González Pérez, II, Civitas, 1993. 
Morillo-Valverde PéreZ, J.I.: «Las situaciones administrativas de los funcionarios en la Ley de Medidas para la Reforma de la Función Pública», REDA, 48, 1985.

NiETo, Alejandro: "La retribución de los funcionarios en España", Revista de Occidente, 1967.

La burocracia, Instituto de Estudios de Administración Local, 1976.

"La Administración y la burocracia del Estado en la década de los 80 ", en Jornadas de Estudio sobre Administraciones y Función Pública en el Estado Autonómico, INAP, 1986.a.

Estudios bistóricos sobre Administración y Derecho Administrativo, INAP, 1986.b

«Función pública local», en el Seminario de Derecho Local, Ed. Ayuntamiento de Barcelona, 1988.

«Reforma administrativa y modernización de la Administración Pública: ¿un problema pendiente?», RVAP, 23, 1989.

«La Administración sirve con objetividad a los intereses generales» en Estudios sobre la Constitución (Homenaje a E. García de Enterría, vol. III, Civitas, 1991).

«Funcionarios y burócratas: el proceso de desburocratización» en el Seminario de Derecho Local, Ed. Ayuntamiento de Barcelona, 1991.

"La jerarquía administrativa", $D A, 229,1992$.

"La carrera administrativa", Cuadernos de Derecho Judicial, Consejo General del Poder Judicial, 1993a.

"La eterna reforma de la función pública», en La Función Pública a debate, Sevilla, 1993b.

Derecho Administrativo Sancionador, Tecnos, 1994.

La nueva organización de desgobierno, Ariel, 1996.

NIGRO, M.: Studi sulla funzione organizatrice della pubblica amministratione, Milano, 1996.

NOGUERA LOPEZ, Alba: «El acceso a la función pública autonómica del personal interino y contratado administrativo: la ausencia de pruebas específicas (comentario a la sentencia del Tribunal Constitucional 302/1993, de 21 de octubre)", Autonomías 18, 1994.

OJEDA AvLLEs: «El empleo temporal en las Administraciones Públicas», REDA, 56, 1987.

"Los limites del paradigma laboral en la función pública», Relaciones Laborales, 3, 1991.

OTAOLA, Javier: «El procedimiento de selección de los funcionarios de la Ertzantxa. Estado de la cuestión", RVAP, 26, 1990.

Palomar Olmeda, Alberto: Derecho de la Función Pública. Régimen juridico de los funcionarios públicos, Dyckinson, 1996.

«Planes de empleo y reforma administrativa», Revista Gestión y Análisis de Politicas Públicas», 2, 1995.

«La incidencia de las nuevas reformas de la Función Pública en la redefinición del Estatuto de los funcionarios públicos", RAP, 134, 1994.

Planificación de los recursos humanos en el ámbito público, McGrawHill, 1997.

Parada VAZQuez, Ramón: Derecho Administrativo y empleo público, II, Marcial Pons, 1996. 
Parejo Alfonso, Luciano: Estado social y Administración pública. Los postulados constitucionales de la reforma administrativa, Civitas, 1983.

«La eficacia como principio jurídico de la actuación de la Administración pública", $D A, 218-219,1989$.

Crisis y renovación en el Derecho Público, Centro de Estudios Constitucionales, 1991.

Eficacia y Administración. Tres estudios, INAP, 1995.

PÉREZ MARTÍNEZ, V.: «El personal laboral al servicio de la Administración y la laboralización de la Función Pública", REALA, 234, 1988.

PRADOS REYES, Francisco: «Las peculiaridades de la relación de trabajo en el empleo público", Actualidad Administrativa, 16-17, 1990.

Prats CaTAlA, Joan: «Derecho y Management en las Administraciones Públicas". Revista Vasca de Economía, 26, 1993.

«Política, gestión y administración de los recursos humanos en las Administraciones Públicas", DA, 210-211, 1087.

"La modernización administrativa en las democracias avanzadas: las políticas de los ochenta. Contenidos, marcos conceptuales y estrategias", Papers ESADE, 82, 1992.

"Los fundamentos institucionales del sistema de mérito: la obligada distinción entre función pública y empleo público", $D A$ núm. 241-242, eneroagosto 1995.

PRIETO DE PedRo, Jesús: Lenguas, lenguaje y Derecho, Civitas, 1991.

REY GUANTER, Salvador del: Estado, Sindicatos, relaciones colectivas en la función pública, INAP, 1985.

«Evolución general y problemática fundamental de las relaciones colectivas en la función pública" en Seminario sobre relaciones colectivas en la Función Pública, 1989.

RIVERo LAMAS, J.: «Modificación sustancial de las condiciones de trabajo, en Estudios de Homenaje a Manuel Alonso García, 1995.

RODRIGUEZ FERNANDEZ, Andrés: Los recursos bumanos en las Administraciones Públicas, Tecnos, 1995.

Rodríguez PIÑero, Miguel: «Trabajo, Función Pública y Constitución», en Seminario sobre relaciones colectivas en la Función Pública, 1989.

ROMÁN, M.D.: Poder de dirección y contrato de trabajo, 1992.

RUIZ IRIARTE, $\mathrm{M}^{\mathbf{a}}$ Rosario: Técnicas psicosociales en la Administración Pública, INAP, 1984, con prólogo de Alejandro Nieto.

SALA Franco, Tomás: La reforma del mercado de trabajo, 1994.

«La movilidad funcional», Relaciones laborales, 17-18, $1994 \mathrm{~b}$.

Incidencia de la legislación laboral en el marco de la Función Pública, INAP, 1989.

SÁNCHEZ MORÓN, Miguel: Derecho de la Función Pública, Tecnos, 1996.

Santamaría Pastor, Juan Alfonso: Prólogo al libro de Escuin Palop: $E l$ acceso del personal y la provisión de puestos: de trabajo en la Administración del Estado y en la Comunidades Autónomas, Tecnos, 1986.

"La teoría del órgano en el Derecho Administrativo", REDA, 40-41, 1984.

"Gobierno y Administración: Una reflexión preliminar", $D A, 1988$. 
SUAY RINCÓN, José: «La reforma de la función pública. Su impacto sobre la burocracia española", $R E D A, 56,1987$.

SUBIRATS, Joan: Análisis de politicas públicas y eficacia de la Administración, INAP, 1989.

VÁZquEZ DE PRADA, Valentín R.: «El funcionario público: señas de identidad", REDA.

ZILLER, Jacques: Egalité et mérite. L'accès a la fonction publique dans les Etats de la Communauté Européenne, Institut Européenne d'Administration Publique, 1988.

Administrations comparées. Les systèmes polítique-administratifs de l'Europe des Douze, Montchrestien, 1993. 
DA-1994-1995, núms. 241-242. MA`NUEL FÉREZ. El sistema de mérito en el empleo público: prin...

DA-1994-1995, núms. 241-242. MANUEL'FÉREZ. El sistema de mérito en el empleo público: prin... 